\title{
Electron ionization of the nucleobases adenine and hypoxanthine near the threshold: A combined experimental and theoretical study
}

\author{
M. Michele Dawley ${ }^{1, \dagger}$, Katrin Tanzer ${ }^{3, \dagger}$, William A. Cantrell ${ }^{1, \dagger}$, Peter Plattner $^{3}$, \\ Nicole R. Brinkmann ${ }^{1}$, Paul Scheier ${ }^{3}$, Stephan Denifl ${ }^{3, a)}$, and Sylwia Ptasińska ${ }^{1,2, a)}$ \\ ${ }^{1}$ Radiation Laboratory and ${ }^{2}$ Department of Physics, University of Notre Dame, Notre Dame, Indiana 46556, USA \\ ${ }^{3}$ Institut für Ionenphysik, Leopold Franzens Universität Innsbruck, Technikerstr. 25, A-6020 Innsbruck, Austria
}

$\dagger$ These authors contributed equally.

\section{ABSTRACT}

Electron ionization of the DNA nucleobase, adenine, and the tRNA nucleobase, hypoxanthine, was investigated near the threshold region $(\sim 5-20 \mathrm{eV})$ using a high-resolution hemispherical electron monochromator and a quadrupole mass spectrometer. Ion efficiency curves of the threshold regions and the corresponding appearance energies (AEs) are presented for the parent cations and the five most abundant fragment cations of each molecule. For the parent cations of adenine and hypoxanthine, the experimental ionization energies (IEs) were determined to be $8.70 \pm 0.3$ and $8.88 \pm 0.5 \mathrm{eV}$, respectively. Quantum chemical calculations (B3LYP/6-311+G(2d,p)) yielded a vertical IE of $8.08 \mathrm{eV}$ and an adiabatic IE of $8.07 \mathrm{eV}$ for adenine and a vertical IE of $8.51 \mathrm{eV}$ and an adiabatic IE of $8.36 \mathrm{eV}$ for hypoxanthine, and the lowest energy optimized structures of the fragment cations and their respective neutrals were calculated. The enthalpies of the possible reactions from adenine and hypoxanthine were also determined computationally, which assisted in determining the most likely electron ionization pathways leading to the major cations. Our results suggest that the imidazole ring is more stable than the pyrimidine ring in several of the

\footnotetext{
a) Authors to whom correspondence should be addressed.

Sylwia Ptasińska - Electronic mail: Sylwia.Ptasinska.1@nd.edu. Telephone: (574) 631-4506. Postal Address: Radiation Laboratory, University of Notre Dame, Notre Dame, IN 46556 USA. 
fragmentation reactions from both adenine and hypoxanthine. This electron ionization study contributes to understanding the biological effects of electrons on nucleobases and contributes to the database of electronic properties of biomolecules, which is necessary for modeling damage of DNA in living cells that is induced by ionizing radiation.

KEYWORDS appearance energy, cation, nucleobase, low energy electron, ion efficiency curve, purine, ionization energy, DNA, DFT, B3LYP, Ab initio

\section{INTRODUCTION}

Nucleobases are of interest to the radiation research community because they are biochemical molecules in cells that can be damaged by impinging ionizing radiation released by natural and artificial sources (e.g., in radiation therapy, nuclear reactor accidents $)^{1-3}$. Adenine, a purine nucleobase, has a significant role in biochemistry because it is a main component of DNA and ATP (the molecule responsible for transporting energy in cells), thus contributing to both protein synthesis and cellular respiration. Hypoxanthine is a modified purine nucleobase that can be formed from the oxidative deamination of adenine and is present in tRNA, which is necessary for protein translation in cells. Hypoxanthine is similar to adenine as both contain a 9-membered double ring structure; however, hypoxanthine carries a carbonyl group in the place of the primary amine group on the pyrimidine ring, as shown in Fig. 1.

The biological effects of high energy radiation in living cells are usually not produced by the impact of primary radiation but rather by the large quantity of secondary particles (i.e., photons, radicals, ions, and low energy electrons) generated along the radiation track ${ }^{4}$. Low energy $(<30 \mathrm{eV})$ secondary electrons are the most abundant of such secondary species and are particularly relevant to interactions with nucleobases because they have been shown to induce both single ${ }^{5,6}$ and double 
strand breaks in DNA ${ }^{6,7}$, causing cell death. Additionally, Monte Carlo simulations, which can be used to model the effects of radiation damage on cells, require a detailed knowledge of the products resulting from DNA damage of biomolecules. These simulations need to include electron collision cross sections and the associated reaction rates, which can be determined from low energy electron studies $^{8,9}$; thus, experimental studies are crucial to biochemical modeling.

Secondary low energy electrons from ionizing radiation (i.e., cosmic rays, etc) can also interact with biomolecules that are present in space. Electron interactions with biologically-relevant molecules are important to investigate because of the potential chemical transformations that can be induced ${ }^{10}$. Adenine can result from smaller molecules under likely prebiotic conditions ${ }^{11-13}$, and it has been found in meteorites ${ }^{14}$. Additionally, a possible precursor of adenine, cyanomethanimine, has been detected in the interstellar medium ${ }^{15}$. Thus, adenine is interesting to the astrobiology community because of its potential role in the synthesis of larger biocomplexes ${ }^{10}$. Hypoxanthine is also a nucleobase of interest because it has been detected in meteorites in ppm concentrations ${ }^{14,16,17}$ and is a possible prebiotic molecule that can be formed from smaller molecules, such as formamide, under UV irradiation and heat and in the presence of minerals ${ }^{11}$.

The importance of the nucleobases for radiation chemistry and physics led to strong interest in the knowledge of their ionization energies (IEs). For example, a very early work by Lifschitz et al. determined IEs of several purines, including adenine, using mass spectrometry ${ }^{18}$. Then, the vertical IEs of several nucleobases, including adenine, were determined using HeI photoelectron spectroscopy ${ }^{19}$. Both studies published the IE for the adenine parent but not appearance energies for its fragments. Several more recent photoionization studies have also been published for adenine, which report more accurately determined $\mathrm{IEs}^{20-23}$. However, only two of these works ${ }^{20,21}$ have provided the photon impact appearance energies (AEs) for several fragment cations from adenine, which are useful for comparison in the present electron ionization study. An early experimental electron ionization 
study selectively labeled adenines to determine the likely reaction pathways ${ }^{24}$. Also, one recent electron collision study of adenine and guanine provides the absolute cross sections for the positive fragments from adenine up to $200 \mathrm{eV}$ as well as the IE for the parent determined from the course $\operatorname{scan}^{25}$. But to our knowledge, there are no detailed electron ionization measurements near the threshold region of both the parent and cationic fragment AEs for adenine. Several computational studies have published vertical ${ }^{26-28}$ and adiabatic ${ }^{25,29}$ IEs for adenine and two provide the optimized structure of adenine $e^{25,28}$. The electron impact cross sections have also been calculated for adenine ${ }^{30}$, and there is one computational study on the probable cleavage sites of adenine based upon which bond lengths change the most upon ionization ${ }^{25}$. However, the calculated enthalpies for the major reaction pathways have not been provided in the literature to date. As for hypoxanthine, the before-mentioned work of Lifschitz et al. ${ }^{18}$ as well as a study by Hush et al. ${ }^{19}$ provided the experimental IE of the parent hypoxanthine molecule. However, there has been only one photoionization study of hypoxanthine, which provides the fragments but not their $\mathrm{AEs}^{31}$. There are currently no experimental electron ionization studies of both the hypoxanthine parent and cationic fragments, and such electron studies likely yield different AEs for the cationic fragments compared to photoionization. Also, detailed and accurate ion efficiency curves near the threshold regions of the fragment cations from electron ionization of either adenine or hypoxanthine as well as supporting computations are currently lacking in the literature. From a computational standpoint, the tautomers of hypoxanthine have been studied ${ }^{32}$ but not the dissociation pathways induced by electron ionization. More broadly, of the other main nucleobases, thymine $e^{8,33}$, uracil ${ }^{34}$, guanine $e^{25,35}$, and cytosine $e^{36,37}$ have been studied experimentally upon electron ionization, and some studies of nucleobases ${ }^{1,25,29,38,39}$ have performed high-level quantum chemical calculations to determine the most stable fragmentation pathways upon electron ionization to assist with interpretation of the experimental data. 
In this study, we report the ion efficiency curves and AEs for the five most abundant cations formed upon electron ionization at a high electron energy resolution from both adenine and hypoxanthine, whose molecular structures are given in Fig. 1. The parent cation results presented here are compared to other IE studies of adenine and hypoxanthine ${ }^{18,19,25,29}$, and the product cations are compared with those from photoionization studies ${ }^{20,21,31}$ and a recent electron ionization study ${ }^{25}$ of adenine and hypoxanthine. The most probable fragmentation products (cation and its neutral counterpart) are also suggested based upon the lowest energy computationally-determined structures and enthalpies of possible reactions for both adenine and hypoxanthine. Because of their similar structures but different functions within the body, the comparison of the interaction of adenine and hypoxanthine with low energy electrons is of fundamental interest. Thus, the formation mechanism of the cations from hypoxanthine is also directly compared to the formation of the similar fragments from adenine.

Similar to our previous electron ionization studies ${ }^{40,41}$, here we define an AE as the least amount of energy necessary for an electron to produce a parent or fragment cation. AEs of the positive ions formed upon electron ionization of adenine (Ade) and hypoxanthine (Hypo) were determined from the threshold regions of the experimentally-obtained ion efficiency curves, while computations of the optimized structures were used to determine enthalpies of the possible reaction pathways. The reactions are presented according to the following general schemes:

$\mathrm{e}^{-}+$Ade $\rightarrow$ cationic fragment + neutral fragment $(\mathrm{s})+2 \mathrm{e}^{-}$

$\mathrm{e}^{-}+$Hypo $\rightarrow$ cationic fragment + neutral fragment $(\mathrm{s})+2 \mathrm{e}^{-}$

Multiple fragmentation pathways leading to several different cations and associated neutrals are possible, and this investigation explores the electron ionization lowest energy pathways for adenine and hypoxanthine.

\section{EXPERIMENTAL SETUP AND DATA ANALYSIS}


The electron ionization of adenine and hypoxanthine was investigated in a high vacuum chamber (base pressure $\sim 8 \times 10^{-8} \mathrm{mbar}$ ) in the Innsbruck Nano-Bio-Physics laboratory. This instrument has been described in detail previously ${ }^{40-42}$. Briefly, it consists of a high-resolution hemispherical electron monochromator (HEM) that produces an electron beam that was crossed with a molecular beam of the samples. The electron beam from the HEM has a typical energy resolution of 100-140 meV (full width at half maximum (FWHM)) at typical electron currents of $\sim 10 \mathrm{nA}^{43}$. The neutral molecular beam of adenine or hypoxanthine was produced by heating the powders in a copper oven inside the chamber to increase their partial pressures. The beam was then emitted from a capillary attached to the copper oven. Ions formed by the interaction with the electrons from the HEM were extracted by a weak electric field towards the entrance of a quadrupole mass spectrometer (QMS), and detection of the ions was achieved by a channeltron-type secondary electron multiplier (SEM).

Adenine $\left(\mathrm{C}_{5} \mathrm{H}_{5} \mathrm{~N}_{5}, \quad \mathrm{MW}=135 \mathrm{~g} / \mathrm{mol}\right)$ of a stated purity of $\geq 99 \%$ and hypoxanthine $\left(\mathrm{C}_{5} \mathrm{H}_{4} \mathrm{~N}_{4} \mathrm{O}, \mathrm{MW}=136 \mathrm{~g} / \mathrm{mol}\right)$ of a stated purity of $\geq 99.0 \%$ were both purchased from Sigma-Aldrich in the form of white crystalline powders. Adenine was heated to $\sim 421 \mathrm{~K}$ in the oven, which is below its melting point of $633 \mathrm{~K}$. Hypoxanthine was heated to $\sim 453 \mathrm{~K}$ in the oven, which is below its melting point of $\sim 573 \mathrm{~K}^{44}$. Temperatures were measured by a Pt100 resistor mounted directly to the oven wall. When the oven was heated and the samples were evaporated, the working pressure in the chamber was typically $\sim 2 \times 10^{-7}$ mbar. Additionally, care was taken to prevent thermal decomposition of the molecules. At $373 \mathrm{~K}$, the decomposition half-life of adenine has been reported to be 1 year, with hypoxanthine and aminoimidazole carboxamide (AICA, MW=126 $\mathrm{g} / \mathrm{mol}$ ) being the known decomposition products ${ }^{45}$. Although adenine was heated to a slightly higher temperature $(\sim 421 \mathrm{~K})$, the time of one set of experiments was less than 1 week, and AICA was never observed in the mass spectra. Additionally, only the most stable $9 \mathrm{H}$-adenine ${ }^{46}$ tautomer, which is protonated at the N9 
location, should be present when adenine is evaporated ${ }^{22,47}$. For hypoxanthine, the half-life has been reported to be much shorter, about 12 days at $373 \mathrm{~K}^{45}$. Although it was necessary to heat to $\sim 453 \mathrm{~K}$ to evaporate hypoxanthine, experiments were performed quickly (within only a few days of initial heating) to prevent decomposition. The mass spectra were monitored for the main decomposition product, AICA. When this product was observed, a new sample was immediately placed in the oven. Experiments were then repeated and continued with a fresh sample as needed.

Typical experiments included recording the mass spectra as a function of temperature until the parent ion was observed with a sufficiently high signal. The temperature of the oven was then kept constant to obtain ion efficiency curves of the most abundant product ions observed in the mass spectra. Ion efficiency curves were recorded in energy ranges from approximately $5 \mathrm{eV}$ below the threshold to approximately $7 \mathrm{eV}$ above the threshold. Approximately 30 scans for each mass were recorded and averaged. The energy scale was calibrated to the well-known IE of helium $(24.6 \mathrm{eV})^{48}$ by backfilling helium into the chamber to a pressure of $\sim 2 \times 10^{-6}$ mbar and measuring the ion efficiency curves of $m / z 4$ before and after each sample experiment.

The AEs of the cations formed from electron ionization of adenine and hypoxanthine were determined by fitting a Wannier-type fitting function ${ }^{49}$ to the experimentally-obtained ion efficiency curves. This fitting method will be described in detail in a future publication [K. Tanzer, C. Matias, J. Postler, L. Sieberer, C.A. Mayhew, P. Scheier, S. Denifl (to be published)] and is an extension of prior fitting methods ${ }^{40-42}$. Briefly, the behavior of the ionization cross section close to the threshold has been described by Wigner's formula ${ }^{50}$ and was later extended by Wannier ${ }^{49}$ as follows:

$$
\sigma=C(E-A E)^{n}
$$

where $\sigma$ is the cross section, AE is the appearance energy, $C$ is the slope of the cross section, $n$ is an exponent that can be theoretically determined only for hydrogen, and $E$ is the electron energy. Because 
the above equation only describes the behavior very close to the actual IE, a Heaviside step function, $\theta$, was added as follows:

$$
\sigma=C(E-A E)^{n} \theta(E-A E)
$$

Because under experimental conditions there is a limited energy resolution of the electron beam, this can also be approximated by a Gaussian distribution and has to be convoluted with the theoretical prediction as follows:

$$
\sigma=\left[C(E-A E)^{n} \theta(E-A E)\right] \frac{1}{\sqrt{2 \pi \rho}} e^{\left\{-\frac{1}{2}\left[\frac{(E)}{\rho}\right]^{2}\right\}}
$$

where $\rho$ denotes the standard deviation of the Gaussian and represents the energy resolution (typically kept at $1 \mathrm{eV})$. By executing a trivial convolution and including a parabolic cylinder function, $D_{-}(n+1)$, the following fitting function can be obtained:

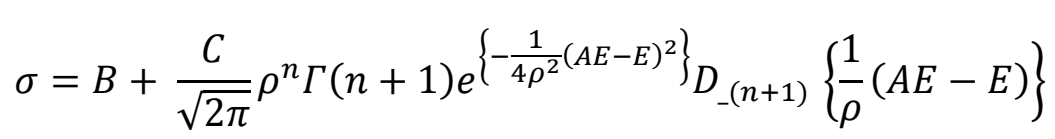

where $B$ is the linear background and $\Gamma(n+1)$ is the gamma function, an extension of the factorial function. This approach allows the fitting of all the parameters of the function, including energy resolution, background, and the exponent, to the experimental data to obtain the AEs. A software tool was created in $\mathrm{Python}^{51}$ programming language in conjunction with $\mathrm{SciPy}^{52}, \mathrm{NumPy}^{53}$, and the 2D plotting library, Matplotlib ${ }^{54}$, by the Innsbruck laboratory to batch process the data with different settings. The energy resolution value with which the data was acquired had a crucial influence on the AEs obtained when fitting the function to the data. The exponent also played a critical role and was also treated with care. The necessary inputs included the energy resolution and electron energy range, while the linear background, a starting value for the AE, and an offset could also be included but were not necessary. Errors for the obtained AEs were determined by fitting each data set to several different reasonable ranges and then taking the mean value. 


\section{COMPUTATIONAL DETAILS}

Quantum chemical computations were used to determine the most likely resulting fragments from the dissociation process. Because only the masses of the structures could be determined from the experiment, the geometries of all possible cationic fragments at specified masses were optimized. Harmonic frequencies were computed to confirm the structure minima and to obtain zero-point corrections to absolute energies. In some cases, more than one fragment had a specific mass, and for those, we calculated all possible cations and the most likely corresponding neutrals to identify the lowest energy resulting fragments (e.g., for the $\mathrm{m} / z 108$ cation from hypoxanthine, both $\mathrm{C}_{4} \mathrm{H}_{2} \mathrm{~N}_{3} \mathrm{O}^{+}$and $\mathrm{C}_{4} \mathrm{H}_{4} \mathrm{~N}_{4}{ }^{+}$with their respective possible neutrals were considered). The most energetically stable combination, determined by calculating reaction enthalpies, was then used to determine the most probable fragment cation for that mass. All computations were performed using the Gaussian 09 program package ${ }^{55}$, and the methods have been described previously ${ }^{56}$. Briefly, B3LYP ${ }^{57,58}$ with the $6-311+\mathrm{G}(2 \mathrm{~d}, \mathrm{p})^{59,60}$ basis set was used in all geometry optimizations and frequency calculations. This basis set is obtained for $\mathrm{H}, \mathrm{C}, \mathrm{N}$, and $\mathrm{O}$ from the $6-311$ basis $^{61}$ by adding diffuse functions and two sets of $\mathrm{d}$ functions on oxygen atoms and two sets of $\mathrm{p}$ functions on hydrogen. The basis set has the following contraction schemes: $\mathrm{H}(6 \mathrm{~s}, 2 \mathrm{p} / 4 \mathrm{~s}, 2 \mathrm{p}), \quad \mathrm{C}(12 \mathrm{~s}, 6 \mathrm{p}, 2 \mathrm{~d} / 5 \mathrm{~s}, 4 \mathrm{p}, 2 \mathrm{~d}), \quad \mathrm{N}(12 \mathrm{~s}, 6 \mathrm{p}, 2 \mathrm{~d} / 5 \mathrm{~s}, 4 \mathrm{p}, 2 \mathrm{~d})$, $\mathrm{O}(12 \mathrm{~s}, 6 \mathrm{p}, 2 \mathrm{~d} / 5 \mathrm{~s}, 4 \mathrm{p}, 2 \mathrm{~d})$.

\section{RESULTS AND DISCUSSION}

\subsection{Mass spectra of adenine and hypoxanthine}

Mass spectra of the cations formed from adenine and hypoxanthine by electron ionization of the neutral molecules at an electron energy of $70 \mathrm{eV}$ are shown in Fig. 2. The parent cations and the five most abundant fragments from each molecule in the mass range of $\mathrm{m} / \mathrm{z} 25-150$ are labeled. For adenine, these include: $\mathrm{C}_{5} \mathrm{H}_{5} \mathrm{~N}_{5}{ }^{+}(m / z 135), \mathrm{C}_{4} \mathrm{H}_{4} \mathrm{~N}_{4}{ }^{+}(m / z 108), \mathrm{C}_{3} \mathrm{H}_{3} \mathrm{~N}_{3}{ }^{+}(m / z 81), \mathrm{C}_{2} \mathrm{H}_{2} \mathrm{~N}_{2}{ }^{+}(m / z 54)$, 
$\mathrm{C}_{2} \mathrm{HN}_{2}{ }^{+}\left(m / z\right.$ 53), and $\mathrm{HCNH}^{+}\left(m / z\right.$ 28). For hypoxanthine, these include: $\mathrm{C}_{5} \mathrm{H}_{4} \mathrm{~N}_{4} \mathrm{O}^{+}(\mathrm{m} / z$ 136), $\mathrm{C}_{4} \mathrm{H}_{2} \mathrm{~N}_{3} \mathrm{O}^{+}\left(m / z\right.$ 108), $\mathrm{C}_{3} \mathrm{H}_{3} \mathrm{~N}_{3}^{+} / \mathrm{C}_{3} \mathrm{HN}_{2} \mathrm{O}^{+}\left(m / z\right.$ 81) $, \mathrm{C}_{2} \mathrm{H}_{2} \mathrm{~N}_{2}^{+} / \mathrm{C}_{2} \mathrm{NO}^{+}(m / z 54), \mathrm{C}_{2} \mathrm{HN}_{2}^{+}(m / z$ 53), and $\mathrm{HCNH}^{+} / \mathrm{CO}^{+}(\mathrm{m} / z$ 28). The cation at $m / z 108$ for hypoxanthine is not one of the five most abundant but was chosen for discussion because of the analogous high signal at this mass in the adenine mass spectrum. With very few exceptions, all of the cations observed for both hypoxanthine and adenine are consistent with those in the NIST spectra ${ }^{48}$. They are also consistent with the mass spectra of adenine and hypoxanthine taken at $70 \mathrm{eV}$, as reported by Rice and Dudek ${ }^{62}$. The most abundant cations from adenine are the same as the most intense ions observed with VUV. The mass spectrum of hypoxanthine is also similar to that reported in a photoionization study taken at $\sim 21 \mathrm{eV}^{31}$ and a recent electron collision study in which the mass spectrum was measured with a $95 \mathrm{eV}$ electron energy ${ }^{25}$. Of note, similar to prior studies, we also observe that adenine displays a higher degree of fragmentation than hypoxanthine at $70 \mathrm{eV}$, in spite of the fact that the 6-membered pyrimidine ring of adenine is fully aromatic and more stable ${ }^{31,62}$. Additionally, our signals for $m / z 28$ were higher than the parent cations for both molecules, which were due to an $\mathrm{N}_{2}$ contribution, as discussed in Sections 4.3 and 4.4.

\subsection{Adenine and hypoxanthine ion efficiency curves}

For the parent cations and the five most abundant fragment cations from adenine and hypoxanthine, we measured ion efficiency curves near the threshold regions and used the fitting procedure (see Section II above) to determine the corresponding AEs. Fig. 3 presents the ion efficiency curves (open circles) and the corresponding fits (solid red curves) for the parent cation of adenine, $\mathrm{C}_{5} \mathrm{H}_{5} \mathrm{~N}_{5}^{+}$, and its fragments, $\mathrm{C}_{4} \mathrm{H}_{4} \mathrm{~N}_{4}{ }^{+}$and $\mathrm{C}_{3} \mathrm{H}_{3} \mathrm{~N}_{3}{ }^{+}$(a) compared to the parent cation of hypoxanthine, $\mathrm{C}_{5} \mathrm{H}_{4} \mathrm{~N}_{4} \mathrm{O}^{+}$, and its fragments, $\mathrm{C}_{4} \mathrm{H}_{4} \mathrm{~N}_{4}{ }^{+} / \mathrm{C}_{4} \mathrm{H}_{2} \mathrm{~N}_{3} \mathrm{O}^{+}$and $\mathrm{C}_{3} \mathrm{H}_{3} \mathrm{~N}_{3}{ }^{+} / \mathrm{C}_{3} \mathrm{HN}_{2} \mathrm{O}^{+}$(b). Fig. 4 presents the ion efficiency curves (open circles) and the corresponding fits (solid red curves) for the fragments, $\mathrm{C}_{2} \mathrm{H}_{2} \mathrm{~N}_{2}{ }^{+}, \mathrm{C}_{2} \mathrm{HN}_{2}{ }^{+}$, and $\mathrm{HCNH}^{+}$, which result from the electron ionization of adenine (a) 
compared to the fragments, $\mathrm{C}_{2} \mathrm{H}_{2} \mathrm{~N}_{2}{ }^{+} / \mathrm{C}_{2} \mathrm{NO}^{+}, \mathrm{C}_{2} \mathrm{HN}_{2}{ }^{+}$, and $\mathrm{HCNH}^{+} / \mathrm{CO}^{+}$, which result from the electron ionization of hypoxanthine (b). Table 1 presents a comparison of the cationic fragments and determined AEs from both molecules. See the Electronic Supplementary Information for Table S1 and S2, which include the other minor cationic fragments from adenine and hypoxanthine, respectively, and their determined AEs from their ion efficiency curves.

\subsection{Adenine and hypoxanthine parent cations}

The parent cation of adenine has an $\mathrm{AE}$ value of $8.70 \pm 0.3 \mathrm{eV}$, which, as expected, is the lowest of all cations measured in this work. From this experimental AE value and the heat of formation $\left(\Delta_{\mathrm{f}} H^{\circ}\right)$ of adenine $(2.13 \mathrm{eV})^{20,}{ }^{63}$, we obtain a $\Delta_{\mathrm{f}} H^{\circ}$ of the parent cation of $\sim 10.83 \pm 0.3 \mathrm{eV}(1045 \mathrm{~kJ} / \mathrm{mol})$, which is higher than reported in the prior photoionization study by Jochims et al. $(998 \pm 11 \mathrm{~kJ} / \mathrm{mol})^{20}$. Our calculated adiabatic and vertical IEs for the optimized structure of the adenine parent cation are $8.07 \mathrm{eV}$ and $8.08 \mathrm{eV}$, respectively, which are both lower than our experimental AE. The experimental AE value is in good agreement with the vertical IE for adenine $(8.91 \pm 0.1 \mathrm{eV})$ measured by Lifschitz et al., who used a semi-logarithmic extrapolation to determine the AEs from mass spectrometry studies ${ }^{18}$. Our experimental AE for adenine is also in good agreement with the electron impact IE $(8.8 \pm 0.2 \mathrm{eV})$ published by Minaev et al. ${ }^{25}$. Similarly, our calculated adiabatic IE is in good agreement with their adiabatic IE (B3LYP/6-31G) of $7.98 \mathrm{eV}^{25}$. Hush and Cheung used HeI photoelectron spectroscopy (PES) to measure the vertical IE of adenine and found a value of $8.44 \mathrm{eV} \pm 0.03 \mathrm{eV}$, which also agrees with our experimental value within error. Several photoionization studies have also reported on the ionization of adenine, which all report slightly lower IEs than our experimental electron ionization AE. Bravaya et al. reported an onset at $8.20 \pm 0.05 \mathrm{eV}$ from their photoionization efficiency curve and a corresponding computed adiabatic IE of $8.13 \mathrm{eV}$ for adenine ${ }^{23}$, which agrees well with our theoretically-determined value. Touboul et al. 
also reported a value of $8.267 \pm 0.005 \mathrm{eV}$ for the IE of gas-phase adenine upon VUV photoionization $^{22}$, and Jochims et al. reported an adiabatic IE of adenine of $8.20 \pm 0.03 \mathrm{eV}$ from their photoionization yield curve $\mathrm{e}^{20}$. Thus, our experimental and theoretical IEs for adenine agree well with those currently in the literature.

In our experiment, the parent cation of hypoxanthine has an onset of $8.88 \pm 0.5 \mathrm{eV}$, which is similar to our AE value for adenine. Our calculated adiabatic and vertical IEs for the hypoxanthine parent cation are 8.36 and $8.51 \mathrm{eV}$, respectively, which are both in good agreement with the experiment. The only previous electron impact IE report of the parent cation for hypoxanthine was by Lifschitz et al. ${ }^{18}$, who reported a value of $9.17 \pm 0.01 \mathrm{eV}$. Hush and Cheung ${ }^{19}$ also measured the vertical IE of hypoxanthine with PES and reported a value of $8.89 \mathrm{eV}$, which agrees very well with our experimental value. A previous photoionization study ${ }^{31}$ of hypoxanthine reported that at $10 \mathrm{eV}$ only the parent cation was observed in the mass spectrum. They also proposed that the positive charge on the parent cation is delocalized over the molecule, resulting in no fragmentation ${ }^{31}$. This is due to ionization of the $\pi$ orbitals, which likely occurs for both adenine and hypoxanthine ${ }^{31}$. Our calculations support both of these assertions, since the electron was shown to be lost from a $\pi$ orbital, and the charge density results showed delocalization of the positive charge throughout the entire molecule. Of note, when compared with electron ionization studies of other nucleobases, the AE values we obtain for the parent cations from adenine and hypoxanthine are both higher than that of guanine $(8.1 \pm 0.2 \mathrm{eV})^{35}$ but are both lower than the $\mathrm{AE}$ of the parent cation from uracil $(9.58 \pm 0.08 \mathrm{eV})^{34}$. One possible reason for the large difference between our AEs and that of uracil could be the differences in their molecular structures. Uracil only contains one ring (a pyrimidine), but adenine, hypoxanthine, and guanine all also contain an imidazole ring, which could lower the IE because of its ability to hold the positive charge. 


\subsection{Major electron-induced cationic fragments from adenine}

A list of possible fragmentation reactions from adenine (involving the most abundant cations) and the calculated reaction enthalpies are shown in Table 2. The optimized lowest energy cation structures from adenine are displayed in Fig. 5, and for those reactions involving an intact neutral, the calculated neutral structures are given in Fig. 6.

The cation $\mathrm{m} / \mathrm{z} 108$ from adenine must represent a conformer of $\mathrm{C}_{4} \mathrm{H}_{4} \mathrm{~N}_{4}{ }^{+}$and is formed according to the following general reaction:

$\mathrm{e}^{-}+\mathrm{C}_{5} \mathrm{H}_{5} \mathrm{~N}_{5} \rightarrow \mathrm{C}_{4} \mathrm{H}_{4} \mathrm{~N}_{4}^{+}+\mathrm{HCN}+2 \mathrm{e}^{-}$

The $\mathrm{C}_{4} \mathrm{H}_{4} \mathrm{~N}_{4}{ }^{+}$species forms via neutral $\mathrm{HCN}$ loss at the $\mathrm{N} 1$ and $\mathrm{C} 2$ positions of the pyrimidine ring (see Fig. 1 for atom numbering) as determined from our calculations of the lowest energy cation for this mass, which is shown in Fig. 5. This structure is in agreement with the recent study by Minaev et al., as shown in their Fig. 7(b) ${ }^{25}$. Additionally, it should be noted that the N3 atom picks up a hydrogen atom in the formation of the most stable conformer. Although our calculations do not explicitly show from where the hydrogen is obtained, it can be inferred that a hydrogen moves from the $\mathrm{NH}_{2}$ group to the $\mathrm{N} 3$ position as the $\mathrm{C}-\mathrm{N}$ bonds break in the pyrimidine ring. Throughout this process, the imidazole ring is kept intact, and the reaction to form this cation and the neutral $\mathrm{HCN}$ has the lowest enthalpy of all the electron-induced fragmentation reactions from adenine $(95.9 \mathrm{kcal} / \mathrm{mol})$. Thus, electron ionization induces pyrimidine ring breakage as one of the most favorable pathways to adenine dissociation. This is contrary to the traditional belief that 6 -membered rings are more stable and have less strain energy than 5-membered rings; the stability of the imidazole ring may be related to the aromaticity of the compound due to orbital overlap. ${ }^{64}$ Of note, Rice and Dudek suggested that the neutral loss of HCN from adenine does not originate from just one site on the parent molecule ${ }^{62}$. However, isotopic studies of adenine observed $>90 \%$ specificity for initial loss of HCN from the N1 and $\mathrm{C} 2$ positions (see Fig. 1) 24, $^{65}$, which is in agreement with our calculated lowest energy fragment at 
$m / z 108$ (see Fig. 5). Additionally, one of the isotopic studies also suggested that N7, N9, and C8 (see Fig. 1) are retained in the $m / z 108\left(\mathrm{C}_{4} \mathrm{H}_{4} \mathrm{~N}_{4}{ }^{+}\right)$cation ${ }^{65}$ of adenine, suggesting that the imidazole ring is stable enough to remain intact during this initial fragmentation, which, as mentioned above, is supported by our calculations. The experimental AE value for the formation of $\mathrm{m} / \mathrm{z} 108$ is $11.70 \pm 0.2 \mathrm{eV}$ in our work (see Fig. 3). Our AE value is close to the $\mathrm{AE}$ value of $11.56 \pm 0.05 \mathrm{eV}$ determined in the photoionization study by Jochims et al. for $m / z 108^{20}$. However, our value is slightly lower than the AE determined for $\mathrm{C}_{4} \mathrm{H}_{4} \mathrm{~N}_{4}{ }^{+}$from adenine $(12.3 \pm 0.1 \mathrm{eV})$ by Pilling et al. using the photo-electron-photoion coincidence technique $(\mathrm{PEPICO})^{21}$. From our determined AE value for $m / z 108$ and the $\Delta_{\mathrm{f}} H^{\circ}$ of adenine $(2.13 \mathrm{eV})^{20,63}$ and $\mathrm{HCN}(1.40 \mathrm{eV})^{63}$, we obtain a $\Delta_{\mathrm{f}} H^{\circ}$ of the $\mathrm{C}_{4} \mathrm{H}_{4} \mathrm{~N}_{4}{ }^{+}$cation from adenine of $\sim 12.43 \pm 0.2 \mathrm{eV}(1199 \mathrm{~kJ} / \mathrm{mol})$, which is within error of the reported value $(1187 \pm 12 \mathrm{~kJ} / \mathrm{mol})$ from photoionization of adenine ${ }^{20}$.

The cation from adenine at $m / z 81\left(\mathrm{C}_{3} \mathrm{H}_{3} \mathrm{~N}_{3}{ }^{+}\right)$has been reported to result from the loss of two neutral HCN molecules ${ }^{20,62}$, as follows:

$\mathrm{e}^{-}+\mathrm{C}_{5} \mathrm{H}_{5} \mathrm{~N}_{5} \rightarrow \mathrm{C}_{3} \mathrm{H}_{3} \mathrm{~N}_{3}^{+}+2 \mathrm{HCN}+2 \mathrm{e}^{-}$

For reaction (4a), we calculated a reaction enthalpy of $102.9 \mathrm{kcal} / \mathrm{mol}$. A recent study by Afrosimov et al. suggests that the $\mathrm{C}_{3} \mathrm{H}_{3} \mathrm{~N}_{3}{ }^{+}$at $m / z 81$ is not formed from the loss of two $\mathrm{HCN}$ groups but rather from loss of the neutral fragment, $\mathrm{C}_{2} \mathrm{H}_{2} \mathrm{~N}_{2}$, from the parent adenine, which they suggest is the more favorable pathway ${ }^{66}$. Thus, we also considered the following reaction in which an intact neutral fragment is the byproduct:

$\mathrm{e}^{-}+\mathrm{C}_{5} \mathrm{H}_{5} \mathrm{~N}_{5} \rightarrow \mathrm{C}_{3} \mathrm{H}_{3} \mathrm{~N}_{3}^{+}+\mathrm{C}_{2} \mathrm{H}_{2} \mathrm{~N}_{2}+2 \mathrm{e}^{-}$

The optimized structure of the $\mathrm{C}_{2} \mathrm{H}_{2} \mathrm{~N}_{2}$ neutral is shown in Fig. 6. However, reaction (4b) requires an enthalpy of $140.1 \mathrm{kcal} / \mathrm{mol}$ according to our calculations and therefore is less favorable than the formation of two neutral HCN molecules (reaction (4a), $102.9 \mathrm{kcal} / \mathrm{mol}$ ). Also, we calculated two low energy conformers for the $m / z 81$ (see Fig. 5) cation $\mathrm{C}_{3} \mathrm{H}_{3} \mathrm{~N}_{3}{ }^{+}$, and we can conclude that it is formed 
from the parent adenine through the loss of two $\mathrm{HCN}$ molecules from the $\mathrm{C} 6, \mathrm{~N} 1$, and $\mathrm{C} 2$ positions on the pyrimidine ring (see Fig. 1) and from the amino group, while the imidazole ring again remains intact similar to the $\mathrm{C}_{4} \mathrm{H}_{4} \mathrm{~N}_{4}{ }^{+}$cation. The lowest energy conformer of the $\mathrm{C}_{3} \mathrm{H}_{3} \mathrm{~N}_{3}{ }^{+}$cation requires $\mathrm{C} 5$ to pick up a hydrogen. While the source of this hydrogen could not be explicitly determined from the calculations, it likely originated from the $\mathrm{NH}_{2}$ group. A second conformer was calculated in which a hydrogen is picked up by $\mathrm{N} 3$, but this structure is $\sim 15 \mathrm{kcal} / \mathrm{mol}(0.65 \mathrm{eV})$ higher in energy than the lowest energy conformer (see Fig. 5 for the structure). Of note, in the recent study by Mineav et al., they suggest that this second conformer (in their Fig. 7(d)) at $m / z 81$ is produced directly from $m / z 108$ but is thermodynamically unstable.

For the fragment ion formed at $m / z 54\left(\mathrm{C}_{2} \mathrm{H}_{2} \mathrm{~N}_{2}{ }^{+}\right)$, two possible reactions are considered:

$$
\begin{aligned}
& \mathrm{e}^{-}+\mathrm{C}_{5} \mathrm{H}_{5} \mathrm{~N}_{5} \rightarrow \mathrm{C}_{2} \mathrm{H}_{2} \mathrm{~N}_{2}^{+}+3 \mathrm{HCN}+2 \mathrm{e}^{-} \\
& \mathrm{e}^{-}+\mathrm{C}_{5} \mathrm{H}_{5} \mathrm{~N}_{5} \rightarrow \mathrm{C}_{2} \mathrm{H}_{2} \mathrm{~N}_{2}^{+}+\mathrm{C}_{3} \mathrm{H}_{3} \mathrm{~N}_{3}+2 \mathrm{e}^{-}
\end{aligned}
$$

The calculated enthalpies for reactions (5a) and (5b) are very similar; and, surprisingly, the formation of the three HCN neutrals is only slightly more favorable (4 kcal/mol less, see Table 2$)$ compared to the loss of a $\mathrm{C}_{3} \mathrm{H}_{3} \mathrm{~N}_{3}$ neutral (see Fig. 6 for the neutral structure). It has been suggested that the loss of multiple HCN molecules can originate from several locations on the adenine molecule, as demonstrated by isotopic studies ${ }^{24,62}$. Our calculations show that to form $\mathrm{C}_{2} \mathrm{H}_{2} \mathrm{~N}_{2}{ }^{+}$the atoms come from either 1) N3, C4, C5, and N7 or from 2) N9, C4, C5, and N7 (see Fig. 1) on the parent adenine. In the study by Mineav et al. ${ }^{25}$, they suggest that the C4-C5 and C4-N9 bonds are weak in the cation at $m / z 81$ (see their Fig. 7(d)) and that it's dissociation results in $\mathrm{m} / \mathrm{z} 54$. Interestingly, in our computations, the C4-C5 bond does not break in the formation of our lowest energy cation at $\mathrm{m} / \mathrm{z} 54$ (see Fig. 5) from the parent adenine. Also, we suggest the formation of $\mathrm{C}_{2} \mathrm{H}_{2} \mathrm{~N}_{2}{ }^{+}$results in disruption of both ring structures (see Fig. 5). Although for reaction (5a) we could not determine the source of the hydrogens in the cation, for the lowest energy cation conformer involving N3, C4, C5, and N7 in 
reaction (5b), two hydrogens are transferred from $\mathrm{C} 8$ and $\mathrm{N} 9$ to the $\mathrm{N} 3$ and $\mathrm{C} 5$ positions. Interestingly, hydrogen transfer to the cation from the $\mathrm{NH}_{2}$ group is not favorable in reaction (5b).

Experimentally, we determined the AE values of $\mathrm{m} / \mathrm{z} 81$ and $\mathrm{m} / \mathrm{z} 54$ from adenine to be $14.14 \pm 0.5 \mathrm{eV}$ and $14.55 \pm 0.3 \mathrm{eV}$, respectively (see Table 1). Based upon the determined AEs of the fragments at $m / z 108,81$, and 54, if the pathways involving $\mathrm{HCN}$ loss are considered (reactions (3), (4a), and (5a)), the successive loss of $\mathrm{HCN}$ groups requires extra energies of 3, 5.44, and $5.85 \mathrm{eV}$ added to the parent cation, respectively. Thus, if fragmentation occurs from $\mathrm{m} / \mathrm{z} 81$ to $\mathrm{m} / \mathrm{z} 54$, it does not require the same energy as and is less difficult than loss of the two initial HCN groups (from $\mathrm{m} / \mathrm{z} 136$ to 108 to 81 ). This suggests that breaking of the imidazole ring is easier after breaking of the pyrimidine ring. The photoionization AEs reported by Jochims et al. for $m / z 81$ and $m / z 54$ from adenine were $12.8 \pm 0.1 \mathrm{eV}$ and $13.7 \pm 0.1 \mathrm{eV}$, respectively ${ }^{20}$, which are both lower than our determined AE values, but their corresponding AEs for all fragments are consistent with the suggestion that the first two HCN losses from adenine are the most difficult thermodynamically [17]. Pilling et al. determined the AEs of $m / z \quad 81$ and $m / z 54$ from adenine to be $12.4 \pm 0.2 \mathrm{eV}$ and $14.4 \pm 0.3 \mathrm{eV}$, respectively ${ }^{21}$, using the photoionization PEPICO technique. Again, their AE value for $m / z 81$ is lower than ours, but their $m / z 54 \mathrm{AE}$ more closely agrees with our experimental electron ionization $\mathrm{AE}$ for this cation. From our determined $\mathrm{AE}$ value for $m / z$ 81, and the $\Delta_{\mathrm{f}} H^{\circ}$ of adenine $(2.13 \mathrm{eV})^{20,63}$ and $\mathrm{HCN}(1.40 \mathrm{eV})^{63}$, we obtain a $\Delta_{\mathrm{f}} H^{\circ}$ of $\sim 13.47 \mathrm{eV}(1300 \mathrm{~kJ} / \mathrm{mol})$ for the $\mathrm{C}_{3} \mathrm{H}_{3} \mathrm{~N}_{3}{ }^{+}$ cation from adenine. Our $\Delta_{\mathrm{f}} H^{\circ}$ is similar to the $\Delta_{\mathrm{f}} H^{\circ}$ of 1,2,3-triazine $(1313 \mathrm{~kJ} / \mathrm{mol})$ and $1,3,5$-triazine $(1194 \mathrm{~kJ} / \mathrm{mol})^{20}$, which have both been considered possible intermediate structures of $\mathrm{C}_{3} \mathrm{H}_{3} \mathrm{~N}_{3}{ }^{+}$. However, our calculations suggest that the $\mathrm{C}_{3} \mathrm{H}_{3} \mathrm{~N}_{3}{ }^{+}$from electron ionization of adenine does not involve these structures; instead we observed that the final optimized cationic structure is a remnant that includes the original 5-membered imidazole ring (see Fig. 5), as discussed above. A similar recent 
computational study ${ }^{25}$ of adenine also excludes the 1,3,5-triazine structure as an intermediate at $m / z 81$.

The cation at $m / z 53\left(\mathrm{C}_{2} \mathrm{HN}_{2}{ }^{+}\right)$from adenine can form via two possible reactions:

$\mathrm{e}^{-}+\mathrm{C}_{5} \mathrm{H}_{5} \mathrm{~N}_{5} \rightarrow \mathrm{C}_{2} \mathrm{HN}_{2}^{+}+3 \mathrm{HCN}+\mathrm{H}+2 \mathrm{e}^{-}$

$\mathrm{e}^{-}+\mathrm{C}_{5} \mathrm{H}_{5} \mathrm{~N}_{5} \rightarrow \mathrm{C}_{2} \mathrm{HN}_{2}^{+}+\mathrm{C}_{3} \mathrm{H}_{4} \mathrm{~N}_{3}+2 \mathrm{e}^{-}$

Experimentally, we determined the $\mathrm{AE}$ to be $16.72 \pm 0.5 \mathrm{eV}$ for the $\mathrm{C}_{2} \mathrm{HN}_{2}{ }^{+}$cation. Interestingly, our calculations revealed that reaction (6b) has a reaction enthalpy that is $79 \mathrm{kcal} / \mathrm{mol}$ lower than reaction (6a) (see Table 2). Thus, reaction (6b), which results in an intact $\mathrm{C}_{3} \mathrm{H}_{4} \mathrm{~N}_{3}$ neutral (see Fig. 6 for structure), is significantly more thermodynamically favorable. While there are multiple possible sources for the $\mathrm{C}_{2} \mathrm{HN}_{2}{ }^{+}$cation, our calculations suggest that it originates from either 1) $\mathrm{C} 5, \mathrm{~N} 7, \mathrm{C}$, and $\mathrm{N} 9$ or from 2) N7, C8, N9, C4 on the parent adenine to form a linear cationic structure. In the first possibility, the N9 retains its hydrogen; however, in the second possibility, the hydrogen is transferred from $\mathrm{C} 8$ or $\mathrm{N} 9$ to N7. Both pathways result in breaking the C4-C5 bond.

Finally, the large signal observed in the mass spectrum at $\mathrm{m} / z 28\left(\mathrm{HCNH}^{+}\right)$from adenine (see Fig. 2) could result from the loss of three neutral $\mathrm{HCN}$ molecules and one neutral $\mathrm{CN}$ fragment upon electron ionization according to the following reaction:

$\mathrm{e}^{-}+\mathrm{C}_{5} \mathrm{H}_{5} \mathrm{~N}_{5} \rightarrow \mathrm{HCNH}^{+}+3 \mathrm{HCN}+\mathrm{CN}+2 \mathrm{e}^{-}$

If reaction (7a) is the dominant pathway, formation of $\mathrm{HCNH}^{+}$results in the breaking of both ring structures. For this reaction, we calculated an enthalpy of $182.6 \mathrm{kcal} / \mathrm{mol}$. Alternatively, an intact neutral $\mathrm{C}_{4} \mathrm{H}_{3} \mathrm{~N}_{4}$ fragment could be lost when $\mathrm{HCNH}^{+}$is formed, according to the following reaction:

$\mathrm{e}^{-}+\mathrm{C}_{5} \mathrm{H}_{5} \mathrm{~N}_{5} \rightarrow \mathrm{HCNH}^{+}+\mathrm{C}_{4} \mathrm{H}_{3} \mathrm{~N}_{4}+2 \mathrm{e}^{-}$

Jochims et al. ${ }^{20}$ and Mineav et al. ${ }^{25}$ have suggested such a route from adenine that involves direct bond breakage and expulsion of the $\mathrm{HCNH}^{+}$to leave the neutral $\mathrm{C}_{4} \mathrm{H}_{3} \mathrm{~N}_{4}$ as shown in reaction (7b). Our calculations show that the enthalpy of reaction ( $7 \mathrm{~b})$ is actually lower, at $148.5 \mathrm{kcal} / \mathrm{mol}$, than reaction 
(7a), which is at $182.6 \mathrm{kcal} / \mathrm{mol}$. The most favorable path for reaction (7b) involves cleavage of the N1 and $\mathrm{C} 2$ from the pyrimidine ring to form the linear cation (see Fig. 5) with the imidazole ring left intact in the neutral (see Fig. 6). $\mathrm{HCNH}^{+}$could also originate from $\mathrm{C} 8$ and $\mathrm{N} 9$ as mentioned by Mineav et al. (see their Fig. 6$)^{25}$, but this reaction requires an additional $15.4 \mathrm{kcal} / \mathrm{mol}$ and is thus slightly less likely. In addition, the C8, N9 pathway is believed to be less favorable because of the tendency of the imidazole ring to remain intact, as seen in the $\mathrm{m} / \mathrm{z} 108$ and $\mathrm{m} / \mathrm{z} 81$ positive ion fragments. Interestingly, from the optimized structure of the neutral by-product, $\mathrm{C}_{4} \mathrm{H}_{3} \mathrm{~N}_{4}$ (see Fig. 6), we could discern that to form $\mathrm{HCNH}^{+}$a hydrogen is picked up from the $\mathrm{N} 9$ position to form the linear conformer rather than from the nearby $\mathrm{NH}_{2}$ group on $\mathrm{C} 6$. We experimentally determined the AE value for $m / z 28$ from adenine to be $13.05 \pm 0.5 \mathrm{eV}$. Our AE is in very good agreement with the AE determined $(13.1 \pm 0.1 \mathrm{eV})$ in the photoionization study by Jochims et al. ${ }^{20}$ and the AE determined $(12.9 \pm 0.3 \mathrm{eV})$ in the photoionization PEPICO study by Pilling et al. ${ }^{21}$, suggesting similar bond dissociation occurs upon electron ionization compared to photoionization. As previously mentioned, the large intensity of $m / z 28$ is due to $\mathrm{N}_{2}{ }^{+}$contribution to the signal. This was confirmed by a second onset $\mathrm{AE}$ at $15.6 \pm 0.2 \mathrm{eV}$, which is assigned to $\mathrm{N}_{2}$ background gas in the chamber.

\subsection{Major electron-induced cationic fragments from hypoxanthine}

A list of possible fragmentation reactions from hypoxanthine and their reaction enthalpies are shown in Table 3. The optimized lowest energy cationic structures from hypoxanthine are displayed in Fig. 7, and for those reactions involving an intact neutral, the optimized neutral structures are provided in Fig. 8. The major cations from electron ionization of hypoxanthine are similar to those of adenine, with a few exceptions due to the presence of the carbonyl group on the hypoxanthine parent structure in place of the primary amine on the $\mathrm{C} 6$ in the pyrimidine ring of the adenine parent structure (see Fig. 1). 
One such exception is the cation at $m / z$ 108, which could result from either 1) loss of a HNCH neutral or expulsion of $\mathrm{HCN}$ and a hydrogen atom to form $\mathrm{C}_{4} \mathrm{H}_{2} \mathrm{~N}_{3} \mathrm{O}^{+}$or from 2) decarbonylation to form $\mathrm{C}_{4} \mathrm{H}_{4} \mathrm{~N}_{4}^{+}$and neutral $\mathrm{CO}^{31,62}$, according to the following reactions:

$\mathrm{e}^{-}+\mathrm{C}_{5} \mathrm{H}_{4} \mathrm{~N}_{4} \mathrm{O} \rightarrow \mathrm{C}_{4} \mathrm{H}_{2} \mathrm{~N}_{3} \mathrm{O}^{+}+\mathrm{HCNH}+2 \mathrm{e}^{-}$

$\mathrm{e}^{-}+\mathrm{C}_{5} \mathrm{H}_{4} \mathrm{~N}_{4} \mathrm{O} \rightarrow \mathrm{C}_{4} \mathrm{H}_{2} \mathrm{~N}_{3} \mathrm{O}^{+}+\mathrm{HCN}+\mathrm{H}+2 \mathrm{e}^{-}$

$\mathrm{e}^{-}+\mathrm{C}_{5} \mathrm{H}_{4} \mathrm{~N}_{4} \mathrm{O} \rightarrow \mathrm{C}_{4} \mathrm{H}_{4} \mathrm{~N}_{4}^{+}+\mathrm{CO}+2 \mathrm{e}^{-}$

For hypoxanthine, the preferred process has been suggested to involve the loss of HCN at the N1 and C2 positions (see Fig. 1) based upon isotopic experiments, ${ }^{62}$ similar to adenine, with the additional loss of a hydrogen atom to form $\mathrm{C}_{4} \mathrm{H}_{2} \mathrm{~N}_{3} \mathrm{O}^{+}$as in reaction (8b). Our calculations do support the loss at the $\mathrm{N} 1$ and $\mathrm{C} 2$ positions, resulting in the lowest energy cation, $\mathrm{C}_{4} \mathrm{H}_{2} \mathrm{~N}_{3} \mathrm{O}^{+}$, as shown in Fig. 7. A second, higher energy optimized structure (with an energy difference of $8.8 \mathrm{kcal} / \mathrm{mol}[0.38 \mathrm{eV}]$ ) is formed via loss at the $\mathrm{C} 8$ and $\mathrm{N} 9$ positions on the imidazole ring with additional breaking of the bond between $\mathrm{C} 4$ and $\mathrm{C} 5$, which results in dissociation of both the pyrimidine and imidazole ring structures. The difference in the formation mechanism of this cation $\left(\mathrm{C}_{4} \mathrm{H}_{2} \mathrm{~N}_{3} \mathrm{O}^{+}\right)$compared to adenine $\left(\mathrm{C}_{4} \mathrm{H}_{4} \mathrm{~N}_{4}{ }^{+}\right)$ is a possible reason for the increased AE value for $m / z 108$ from hypoxanthine $(12.22 \pm 0.22 \mathrm{eV})$ compared to the AE value for $m / z 108$ from adenine $(11.70 \pm 0.2 \mathrm{eV})$. In contrast to the study by Rice et al. $^{62}$, our calculations show that the neutral loss of an intact $\mathrm{HCNH}$ is more favorable thermodynamically (see Table 3 ) than $\mathrm{HCN}+\mathrm{H}$ loss. However, if we also consider the possibility of $\mathrm{C}_{4} \mathrm{H}_{4} \mathrm{~N}_{4}{ }^{+}$as the cation, reaction (8c) involving loss of neutral $\mathrm{CO}$ is overall the most favorable reaction $(22.6 \mathrm{kcal} / \mathrm{mol})$, with the loss of $\mathrm{HCNH}$ (reaction $(8 \mathrm{a}), 122.9 \mathrm{kcal} / \mathrm{mol}$ ) being the second lowest in enthalpy. The very low enthalpy of reaction (8c) is primarily due to the stability of CO. When examining the optimized structure of the cation, $\mathrm{C}_{4} \mathrm{H}_{4} \mathrm{~N}_{4}{ }^{+}$, we observe a double imidazole ring structure that includes all atoms except C6 and the oxygen. However, the energy of this cation was found to be much higher than the lowest energy conformer of $\mathrm{C}_{4} \mathrm{H}_{2} \mathrm{~N}_{3} \mathrm{O}^{+}$. Thus, although the overall 
enthalpy of reaction (8c) is lower, reaction (8a) is most likely the dominant pathway because the energy of the $\mathrm{C}_{4} \mathrm{H}_{2} \mathrm{~N}_{3} \mathrm{O}^{+}$cation is lower. As shown in the mass spectra (see Fig. 2), the relative small intensity of $m / z 108$ from hypoxanthine compared to adenine and compared to other stronger peaks in the mass spectrum suggests that reactions (8a)-(8c) leading to $\mathrm{m} / \mathrm{z} 108$ due to electron ionization are either minor or that the cation quickly dissociates into other fragments. Therefore, even though the imidazole ring is stable compared to the pyrimidine ring initially as observed for the lowest energy conformer of the cation (see Fig. 7), complete dissociation of the ring structure appears to occur easily and results in some lower mass fragments.

From hypoxanthine, $\mathrm{C}_{3} \mathrm{H}_{3} \mathrm{~N}_{3}{ }^{+}$at $m / z 81$ can be formed from loss of $\mathrm{HCN}$ and $\mathrm{CO}$ upon electron ionization, as shown in the following reaction:

$\mathrm{e}^{-}+\mathrm{C}_{5} \mathrm{H}_{4} \mathrm{~N}_{4} \mathrm{O} \rightarrow \mathrm{C}_{3} \mathrm{H}_{3} \mathrm{~N}_{3}^{+}+\mathrm{HCN}+\mathrm{CO}+2 \mathrm{e}^{-}$

The lowest energy structure of $m / z 81$ is found to be $\mathrm{C}_{3} \mathrm{H}_{3} \mathrm{~N}_{3}{ }^{+}$with the imidazole ring remaining intact and loss of $\mathrm{C} 6, \mathrm{~N} 1$, and $\mathrm{C} 2$ and the oxygen, which breaks the pyrimidine ring, similar to $\mathrm{C}_{3} \mathrm{H}_{3} \mathrm{~N}_{3}{ }^{+}$ from adenine. Also similar to adenine, a hydrogen transfers to the $\mathrm{C} 5$ position in the lowest energy cationic structure (see Fig. 7). In a second slightly higher energy conformer $(+15 \mathrm{kcal} / \mathrm{mol}[0.65 \mathrm{eV}])$, the hydrogen transfers to the N3 position (see Fig. 7). Reaction (9a) is thermodynamically favorable, with a reaction enthalpy of $83.9 \mathrm{kcal} / \mathrm{mol}$. However, the small intensity of $\mathrm{m} / \mathrm{z} 81$ in the hypoxanthine mass spectrum (see Fig. 2) suggests that this cation further fragments to smaller masses. We determined an $\mathrm{AE}$ of $13.40 \pm 0.2 \mathrm{eV}$ for $\mathrm{m} / \mathrm{z} 81$ from hypoxanthine, which is interestingly slightly lower than that of $m / z 81$ from adenine (see Fig. 3); the difference likely results from breakage of different bonds during electron ionization of the parent molecules. Of note, we also computationally considered a reaction in which $\mathrm{C}_{2} \mathrm{HNO}$ is the intact neutral instead of $\mathrm{HCN}$ and $\mathrm{CO}$. However, during optimization of the structure, the intact neutral dissociated into $\mathrm{HCN}$ and $\mathrm{CO}$. Thus, the intact neutral 
fragment is not a viable possibility when $\mathrm{C}_{3} \mathrm{H}_{3} \mathrm{~N}_{3}{ }^{+}$is formed. Another possibility for the cation at $m / z 81$ is $\mathrm{C}_{3} \mathrm{HN}_{2} \mathrm{O}^{+}$, so we also considered the following reactions computationally:

$\mathrm{e}^{-}+\mathrm{C}_{5} \mathrm{H}_{4} \mathrm{~N}_{4} \mathrm{O} \rightarrow \mathrm{C}_{3} \mathrm{HN}_{2} \mathrm{O}^{+}+2 \mathrm{HCN}+\mathrm{H}+2 \mathrm{e}^{-}$

$\mathrm{e}^{-}+\mathrm{C}_{5} \mathrm{H}_{4} \mathrm{~N}_{4} \mathrm{O} \rightarrow \mathrm{C}_{3} \mathrm{HN}_{2} \mathrm{O}^{+}+\mathrm{C}_{2} \mathrm{H}_{3} \mathrm{~N}_{2}+2 \mathrm{e}^{-}$

Both of these reactions have significantly higher enthalpies than reaction (9a), so reaction (9a) is most likely the dominant pathway (see Table 3). However, when comparing reactions (9b) and (9c) to each other, the enthalpy for reaction $(9 \mathrm{c})$ is the lowest of the two by $31.7 \mathrm{kcal} / \mathrm{mol}$, suggesting that the intact neutral (see Fig. 8 for structure) is preferential over the loss of two HCN groups and a hydrogen. This agrees with the trend seen for some of the lower mass fragments resulting from the electron ionization of adenine.

Fitting of the experimental data shows that formation of the fragment at $m / z 54$ requires an $\mathrm{AE}$ of $14.10 \pm 0.3 \mathrm{eV}$. This cation is the second most intense signal in the hypoxanthine mass spectrum (see Fig. 2) and could represent $\mathrm{C}_{2} \mathrm{H}_{2} \mathrm{~N}_{2}{ }^{+}$, which could be formed via electron ionization as shown in the following general reactions:

$\mathrm{e}^{-}+\mathrm{C}_{5} \mathrm{H}_{4} \mathrm{~N}_{4} \mathrm{O} \rightarrow \mathrm{C}_{2} \mathrm{H}_{2} \mathrm{~N}_{2}^{+}+2 \mathrm{HCN}+\mathrm{CO}+2 \mathrm{e}^{-}$
$\mathrm{e}^{-}+\mathrm{C}_{5} \mathrm{H}_{4} \mathrm{~N}_{4} \mathrm{O} \rightarrow \mathrm{C}_{2} \mathrm{H}_{2} \mathrm{~N}_{2}^{+}+\mathrm{C}_{3} \mathrm{H}_{2} \mathrm{~N}_{2} \mathrm{O} \rightarrow \mathrm{C}_{2} \mathrm{H}_{2} \mathrm{~N}_{2}^{+}+\mathrm{CO}+\mathrm{C}_{2} \mathrm{H}_{2} \mathrm{~N}_{2}+2 \mathrm{e}^{-}$

Both reactions have been considered in our calculations, and their enthalpies are similar (see Table 3). Interestingly, reaction (10b) is slightly favored thermodynamically over loss of two HCNs and CO. In reaction $(10 \mathrm{~b})$, the calculations unexpectedly show that the intact neutral further dissociates into $\mathrm{CO}$ and $\mathrm{C}_{2} \mathrm{~N}_{2} \mathrm{H}_{2}$ (see Fig. 8). The calculated lowest energy structure for $\mathrm{C}_{2} \mathrm{H}_{2} \mathrm{~N}_{2}^{+}$contains N7, C5, C4, and $\mathrm{N} 3$ (see Fig. 7). The calculated structure of $\mathrm{C}_{2} \mathrm{H}_{2} \mathrm{~N}_{2}{ }^{+}$is the same for both hypoxanthine and adenine and occurs via similar pathways. However, in the case of hypoxanthine, because of the presence of the carbonyl, the neutral products include $\mathrm{CO}$, whereas for adenine, three HCN neutrals are produced 
upon electron ionization to form this cation. Another possible cation for $m / z 54$ from hypoxanthine could be $\mathrm{C}_{2} \mathrm{NO}^{+}$, according to the following reactions:

$\mathrm{e}^{-}+\mathrm{C}_{5} \mathrm{H}_{4} \mathrm{~N}_{4} \mathrm{O} \rightarrow \mathrm{C}_{2} \mathrm{NO}^{+}+3 \mathrm{HCN}+\mathrm{H}+2 \mathrm{e}^{-}$

$\mathrm{e}^{-}+\mathrm{C}_{5} \mathrm{H}_{4} \mathrm{~N}_{4} \mathrm{O} \rightarrow \mathrm{C}_{2} \mathrm{NO}^{+}+\mathrm{C}_{3} \mathrm{H}_{4} \mathrm{~N}_{3}+2 \mathrm{e}^{-}$

These reactions also have low enthalpies, especially reaction (10d), which has an enthalpy of only $119 \mathrm{kcal} / \mathrm{mol}$ and is comparable to the reactions that produce $\mathrm{C}_{2} \mathrm{H}_{2} \mathrm{~N}_{2}{ }^{+}$. In the experiment, both the $\mathrm{C}_{2} \mathrm{H}_{2} \mathrm{~N}_{2}{ }^{+}$and $\mathrm{C}_{2} \mathrm{NO}^{+}$cations may form contributing to the signal at $m / z$ 54. For reaction (10c), a pathway that is not favorable, the calculations show that the cation would consist of $\mathrm{C} 6, \mathrm{C} 5, \mathrm{~N} 7$, and oxygen. However, the cation in the favorable reaction (10d) originates from C6, N1, C2, and oxygen (see Fig. 7 for $\mathrm{C}_{2} \mathrm{NO}^{+}$structure), and the neutral retains the imidazole ring with hydrogen transferred to the $\mathrm{N} 3$ and $\mathrm{C} 5$ positions (see Fig. 8 for $\mathrm{C}_{3} \mathrm{H}_{4} \mathrm{~N}_{3}$ neutral structure). Therefore, the lowest energy conformers for the two reactions originate from different atoms in the parent hypoxanthine, and reaction (10d) is favored because of the stability of the neutral containing the imidazole ring. We also note that reaction (10d) from hypoxanthine has a lower enthalpy than reaction (5a) from adenine, which produces the same $\mathrm{m} / \mathrm{z} 54$ in the mass spectrum. Thus, the most probable cation at $\mathrm{m} / \mathrm{z} 54$ due to electron ionization of hypoxanthine is $\mathrm{C}_{2} \mathrm{NO}^{+}$, while for adenine it is $\mathrm{C}_{2} \mathrm{H}_{2} \mathrm{~N}_{2}{ }^{+}$. This also further suggests that the cation at $\mathrm{m} / \mathrm{z} 53$ might not simply originate from hydrogen loss from the cation at $m / z 54$ in the case of hypoxanthine. The cation at $m / z 53$ requires an $\mathrm{AE}$ of $15.58 \pm 0.5 \mathrm{eV}$ and can, form via the following reactions:

$$
\begin{aligned}
& \mathrm{e}^{-}+\mathrm{C}_{5} \mathrm{H}_{4} \mathrm{~N}_{4} \mathrm{O} \rightarrow \mathrm{C}_{2} \mathrm{HN}_{2}^{+}+2 \mathrm{HCN}+\mathrm{CO}+\mathrm{H}+2 \mathrm{e}^{-} \\
& \mathrm{e}^{-}+\mathrm{C}_{5} \mathrm{H}_{4} \mathrm{~N}_{4} \mathrm{O} \rightarrow \mathrm{C}_{2} \mathrm{HN}_{2}^{+}+\mathrm{C}_{3} \mathrm{H}_{3} \mathrm{~N}_{2} \mathrm{O}+2 \mathrm{e}^{-}
\end{aligned}
$$

Our determined AEs for this cation suggest that less energy is required in the hypoxanthine pathway leading to $\mathrm{m} / \mathrm{z} 53$ compared to adenine (see Table 1). Indeed, when comparing the calculated reaction enthalpies (see Tables 2 and 3), reaction (11a) is lower than the corresponding reaction (6a) from 
adenine by $19 \mathrm{kcal} / \mathrm{mol}$. In reaction (11a), similar to $\mathrm{C}_{2} \mathrm{H}_{2} \mathrm{~N}_{2}{ }^{+}$formed in reaction (10a), two $\mathrm{HCN}$ and a CO neutral are observed for hypoxanthine rather than three HCN neutrals as for adenine. However, for $\mathrm{C}_{2} \mathrm{HN}_{2}{ }^{+}$, an additional hydrogen neutral is lost to form the cation. The enthalpy of reaction (11b) is also lower than the corresponding reaction (6b) from adenine by $15.3 \mathrm{kcal} / \mathrm{mol}$, and in both adenine and hypoxanthine, the intact neutral fragment is favored over $\mathrm{HCN}$ loss when the $\mathrm{C}_{2} \mathrm{HN}_{2}{ }^{+}$cation is formed. The $\mathrm{C}_{3} \mathrm{H}_{3} \mathrm{~N}_{2} \mathrm{O}$ neutral forms a new ring structure, which makes it more stable, and the C5 position picks up a hydrogen (see Fig. 8 for structure). Our calculated lowest energy cation for $\mathrm{m} / \mathrm{z} 53$ has the same linear structure as the cation for $\mathrm{m} / \mathrm{z} 53$ from adenine (see Figs. 5 and 6), and in reaction (11b), the cation originates from N7, C8, N9, and C4. Thus, for the cation produced in reaction (11b), we do not observe that the N1-C6 and C2-N3 bonds are broken, as suggested by the photoionization study by Feyer et al. ${ }^{31}$ However, similar to adenine, the C4-C5 bond is broken to form $\mathrm{C}_{2} \mathrm{HN}_{2}{ }^{+}$in reaction (11b), along with a corresponding intact neutral remnant of the parent. Another alternative pathway from hypoxanthine would be the decarbonylation of the fragment at $m / z 108\left(\mathrm{C}_{4} \mathrm{H}_{2} \mathrm{~N}_{3} \mathrm{O}^{+}\right)$to form $m / z 80\left(\mathrm{C}_{3} \mathrm{H}_{2} \mathrm{~N}_{3}{ }^{+}\right)$and then the subsequent loss of $\mathrm{HCN}$ to also form $m / z 53\left(\mathrm{C}_{2} \mathrm{HN}_{2}{ }^{+}\right)$. Feyer et al. suggested that these fragments $(\mathrm{m} / \mathrm{z} 108,80$, and 53) result from breaking the N1-C6 and C2-N3 bonds (see Fig. 1) in hypoxanthine ${ }^{31}$. Such a fragmentation pattern would leave the imidazole ring of hypoxanthine intact until further bond breakage occurs, which is consistent with what we observe in the lowest energy conformer of $\mathrm{m} / z 108$ from hypoxanthine. However, computationally this combined reaction pathway would involve an enthalpy of $151.9 \mathrm{kcal} / \mathrm{mol}$, which is much higher than the more favorable reaction (11b). Surprisingly, the loss of two HCN molecules (reaction (11a)) is even higher in enthalpy than this alternative three-step pathway (by $\sim 20.9 \mathrm{kcal} / \mathrm{mol}$ ). Thus, overall, reaction $(11 \mathrm{~b})$, which forms the intact neutral by-product with the cation, is likely the dominant pathway, while HCN loss is not as thermodynamically favored. 
The large signal at $\mathrm{m} / \mathrm{z} 28$ can be formed upon electron ionization of hypoxanthine via the following reaction:

$\mathrm{e}^{-}+\mathrm{C}_{5} \mathrm{H}_{4} \mathrm{~N}_{4} \mathrm{O} \rightarrow \mathrm{HCNH}^{+}+2 \mathrm{HCN}+\mathrm{CO}+\mathrm{CN}+2 \mathrm{e}^{-}$

The calculated enthalpy of this reaction is $163.6 \mathrm{kcal} / \mathrm{mol}$ compared to $182.6 \mathrm{kcal} / \mathrm{mol}$ for the analogous reaction from adenine (7a). The presence of the $\mathrm{CO}$ in the case of hypoxanthine makes reaction (12a) more favorable than (7a) in adenine. Formation of the cation in reaction (12a) results in the breaking of both ring structures. Interestingly, even if such ring rupture occurs, formation of this cation does not require a higher $\mathrm{AE}$ than the other major cations. We experimentally determined the AE value for $m / z 28$ from hypoxanthine to be $13.79 \pm 0.4 \mathrm{eV}$, which is slightly higher than the AE value for $\mathrm{m} / \mathrm{z} 28$ from adenine (see Table 1). This increase in energy needed to observe the fragment could be because of the presence of the carbonyl group (see reactions (12a) vs. (7a)) and the different neutral products.

An alternative pathway leads to an intact neutral $\mathrm{C}_{4} \mathrm{H}_{2} \mathrm{~N}_{3} \mathrm{O}$ fragment that could be lost when $\mathrm{HCNH}^{+}$is formed, according to the following reaction:

$\mathrm{e}^{-}+\mathrm{C}_{5} \mathrm{H}_{4} \mathrm{~N}_{4} \mathrm{O} \rightarrow \mathrm{HCNH}^{+}+\mathrm{C}_{4} \mathrm{H}_{2} \mathrm{~N}_{3} \mathrm{O}+2 \mathrm{e}^{-}$

Such a reaction is similar to the possible reaction (7b) for adenine. Interestingly, reaction (12b) is more thermodynamically favorable by $6.9 \mathrm{kcal} / \mathrm{mol}$ than reaction (12a) given above, again supporting the favorability of intact remnant neutrals over neutral HCN loss for lower mass cations. The lowest energy conformer of $\mathrm{HCNH}^{+}$is linear (see Fig. 7), similar to adenine. However, for hypoxanthine, the cation involves $\mathrm{C} 8$ and $\mathrm{N} 9$ from the parent (see Fig. 7 for structure), leaving the pyrimidine ring intact in the neutral by-product (see Fig. 8 for structure). Interestingly, this mechanism is different from what was computationally determined in the case of adenine in which the most stable cation originated from the $\mathrm{N} 1$ and $\mathrm{C} 2$ positions on the parent, and the resulting neutral kept the imidazole, not the pyrimidine, ring intact (see Fig. 6 for structure of the $\mathrm{C}_{4} \mathrm{H}_{3} \mathrm{~N}_{4}$ neutral from adenine). Another simple mechanism 
from hypoxanthine that has been discussed in the literature ${ }^{31}$ could involve the formation of $\mathrm{CO}^{+}$, according to the two following possible reactions:

$\mathrm{e}^{-}+\mathrm{C}_{5} \mathrm{H}_{4} \mathrm{~N}_{4} \mathrm{O} \rightarrow \mathrm{CO}^{+}+4 \mathrm{HCN}+2 \mathrm{e}^{-}$

$\mathrm{e}^{-}+\mathrm{C}_{5} \mathrm{H}_{4} \mathrm{~N}_{4} \mathrm{O} \rightarrow \mathrm{CO}^{+}+\mathrm{C}_{4} \mathrm{H}_{4} \mathrm{~N}_{4}+2 \mathrm{e}^{-}$

where the calculations show that $\mathrm{CO}^{+}$originates from $\mathrm{C} 6$ and the oxygen in the parent hypoxanthine as expected, and in the $\mathrm{C}_{4} \mathrm{H}_{4} \mathrm{~N}_{4}$ neutral, the imidazole ring stays intact and another ring forms from the N3, C2, and N1 (see Fig. 8 for structure). However, both reactions (12c) and (12d) are less favorable thermodynamically than reactions (12a) and (12b) above (see Table 3 ). In fact, reaction (12c) has the highest enthalpy of all four possibilities according to the calculations, and reaction (12d) is only $12 \mathrm{kcal} / \mathrm{mol}$ higher in enthalpy than reaction (12b). Since the reaction enthalpy of (12d) is similar to reaction (12b) and they are the most favorable of the four possibilities, formation of an intact neutral seems preferential to formation of multiple $\mathrm{HCN}$ groups for the lower mass cations. 


\section{CONCLUSIONS}

This is a detailed electron ionization investigation of both adenine and hypoxanthine that reports AEs for the most abundant fragment cations, calculated enthalpies for the possible reactions, and optimized structures for the most stable cations and their corresponding neutrals. Experimentally, we have measured the mass spectra at $70 \mathrm{eV}$ and the ion efficiency curves near the threshold region for the parent cations and five most abundant ion fragments from adenine and hypoxanthine produced upon low energy electron ionization $(<18 \mathrm{eV})$ using a high-resolution hemispherical electron monochromator. The AEs for each cation were determined by fitting a Wannier-type fitting function to the experimental ion efficiency curves. The AEs of the parent cations of adenine and hypoxanthine were determined to be $8.70 \pm 0.3 \mathrm{eV}$ and $8.88 \pm 0.5 \mathrm{eV}$, respectively, which agree well with prior studies and our own calculated adiabatic and vertical transition IEs for the parent cations. The low values for the parent cations could be characteristic of two-ringed purines when compared with pyrimidines.

Adenine's most abundant fragment cations include $\mathrm{C}_{4} \mathrm{H}_{4} \mathrm{~N}_{4}{ }^{+}, \mathrm{C}_{3} \mathrm{H}_{3} \mathrm{~N}_{3}{ }^{+}, \mathrm{C}_{2} \mathrm{H}_{2} \mathrm{~N}_{2}{ }^{+}, \mathrm{C}_{2} \mathrm{HN}_{2}{ }^{+}$, and $\mathrm{HCNH}^{+}$, as determined from experiment and calculations of the most stable cations. The most thermodynamically-favored pathway for adenine dissociation due to electron ionization is initial loss of one $\mathrm{HCN}$ molecule to form $\mathrm{C}_{4} \mathrm{H}_{4} \mathrm{~N}_{4}{ }^{+}$, which involves pyrimidine ring breakage while the imidazole ring is kept intact. The loss of two $\mathrm{HCN}$ molecules to form $\mathrm{C}_{3} \mathrm{H}_{3} \mathrm{~N}_{3}{ }^{+}$is the second most favorable reaction, and again our calculations show that the imidazole ring is kept intact in the cation. Of note, several other studies have suggested that the primary pathway for electron ionization of adenine involves successive loss of $\mathrm{HCN}$ groups $^{20,25,62}$. From our calculated enthalpies, we cannot suggest whether successive $\mathrm{HCN}$ loss or reactions directly from the parent are more favorable. However, upon formation of the $\mathrm{C}_{2} \mathrm{H}_{2} \mathrm{~N}_{2}{ }^{+}$cation, a pathway involving an intact neutral remnant of the parent molecule is competitive with loss of three $\mathrm{HCN}$ molecules. From our experimental AEs, fragmentation that 
could occur from $\mathrm{m} / \mathrm{z} 81$ to $\mathrm{m} / \mathrm{z} 54$ is shown to be less favorable than loss of the initial two HCN groups. Interestingly, the reactions from adenine to form both the $\mathrm{C}_{2} \mathrm{HN}_{2}{ }^{+}$and $\mathrm{HCNH}^{+}$cations are more favorable thermodynamically when an intact neutral remnant is lost instead of neutral HCN molecules. For $\mathrm{HCNH}^{+}$, the determined $\mathrm{AE}$ agrees very well with photoionization studies, suggesting similar bond dissociation to form this cation upon electron ionization compared to photoionization.

Hypoxanthine's most stable fragment cations include $\mathrm{C}_{4} \mathrm{H}_{2} \mathrm{~N}_{3} \mathrm{O}^{+}, \mathrm{C}_{3} \mathrm{H}_{3} \mathrm{~N}_{3}{ }^{+}, \mathrm{C}_{2} \mathrm{H}_{2} \mathrm{~N}_{2}{ }^{+} / \mathrm{C}_{2} \mathrm{NO}^{+}$, $\mathrm{C}_{2} \mathrm{HN}_{2}{ }^{+}$, and $\mathrm{HCNH}^{+} / \mathrm{CO}^{+}$, and because of the presence of the carbonyl group on the 6-membered pyrimidine ring that replaces the amino group of adenine, the available fragmentation pathways are more varied. The three most favorable fragmentation pathways include loss of neutral $\mathrm{CO}$ to form $\mathrm{C}_{4} \mathrm{H}_{4} \mathrm{~N}_{4}{ }^{+}$, loss of neutral $\mathrm{HCN}$ and $\mathrm{CO}$ to form $\mathrm{C}_{3} \mathrm{H}_{3} \mathrm{~N}_{3}{ }^{+}$, and loss of an intact neutral remnant to form $\mathrm{C}_{2} \mathrm{HN}_{2}{ }^{+}$. For $m / z 108$ from hypoxanthine, the $\mathrm{C}_{4} \mathrm{H}_{2} \mathrm{~N}_{3} \mathrm{O}^{+}$ion is the most stable cation, but due to the loss of a stable $\mathrm{CO}$ molecule, the reaction to form the $\mathrm{C}_{4} \mathrm{H}_{4} \mathrm{~N}_{4}{ }^{+}$has a lower enthalpy. In contrast to adenine, the weak intensity of the $m / z 108$ in the hypoxanthine mass spectrum suggests that this cation quickly dissociates to smaller mass fragments. When $\mathrm{C}_{3} \mathrm{H}_{3} \mathrm{~N}_{3}{ }^{+}$is formed from hypoxanthine, the imidazole ring again remains intact, similar to the same cation from adenine. For $\mathrm{m} / \mathrm{z}$ 54, two possibilities for the cation were considered, $\mathrm{C}_{2} \mathrm{H}_{2} \mathrm{~N}_{2}{ }^{+}$and $\mathrm{C}_{2} \mathrm{NO}^{+}$, and both are competitive thermodynamically. Regardless of the cation structure, similar to adenine, for this low mass cation, the loss of an intact neutral remnant from the parent is competitive or even preferential to the loss of $\mathrm{HCN}$ molecules. This trend continues in the formation of both $\mathrm{C}_{2} \mathrm{HN}_{2}{ }^{+}$and $\mathrm{HCNH}^{+}$from hypoxanthine, similar to adenine. For $m / z 28$, the reaction pathway leading to $\mathrm{CO}^{+}$and an intact neutral remnant is competitive with the formation of $\mathrm{HCNH}^{+}$. Overall, our study contributes to understanding the effects of radiation on nucleobases, which are building blocks in several biochemical processes, and such studies are useful to the radiation therapy and biochemical modeling communities.

\section{ACKNOWLEDGMENTS}


The research described herein was partially supported by the Division of Chemical Sciences, Geosciences and Biosciences, Basic Energy Sciences, Office of Science, United States Department of Energy (DOE) through Grant No. DE-FC02-04ER15533. This is Radiation Laboratory contribution number NDRL-5031. This work has also been supported by the Fonds zur Förderung der wissenschaftlichen Forschung (Austrian Science Fund (FWF) P22665). The authors would also like to thank C. Matias, J. Postler, L. Sieberer, and C.A. Mayhew for their contributions to the AE fitting method and programs. 


\section{ELECTRONIC SUPPLEMENTARY INFORMATION (ESI)}

The other minor cationic fragments from adenine and hypoxanthine including their experimentally-determined AEs as well as the calculated (B3LYP/6-311+G(2d,p)) absolute energies and zero-point corrected energies (ZPE) for the most stable cations and neutral conformers from adenine and hypoxanthine are provided in the Electronic Supplementary Information, which can be found at http://pubs.rsc.org. 


\section{TABLES}

Table 1. Comparison of appearance energies (AEs) for the major cations produced upon electron ionization of adenine and hypoxanthine.

\begin{tabular}{|l|c|c|l|c|c|}
\hline \multicolumn{3}{|c|}{ Adenine } & \multicolumn{3}{c|}{ Hypoxanthine } \\
\hline $\begin{array}{l}\text { Cationic } \\
\text { fragment }\end{array}$ & $\begin{array}{c}\text { Mass } \\
(\mathrm{m} / \mathrm{z})\end{array}$ & $\begin{array}{r}\text { Experimental } \\
\mathrm{AE}(\mathrm{eV})\end{array}$ & $\begin{array}{l}\text { Cationic } \\
\text { fragment }\end{array}$ & $\begin{array}{c}\text { Mass } \\
(\mathrm{m} / \mathrm{z})\end{array}$ & $\begin{array}{r}\text { Experimental } \\
\text { AE (eV) }\end{array}$ \\
\hline $\mathrm{C}_{5} \mathrm{H}_{5} \mathrm{~N}_{5}^{+}$ & 135 & $8.70 \pm 0.3$ & $\mathrm{C}_{5} \mathrm{H}_{4} \mathrm{~N}_{4} \mathrm{O}^{+}$ & 136 & $8.88 \pm 0.5$ \\
\hline $\mathrm{C}_{4} \mathrm{H}_{4} \mathrm{~N}_{4}^{+}$ & 108 & $11.70 \pm 0.2$ & $\begin{array}{l}\mathrm{C}_{4} \mathrm{H}_{4} \mathrm{~N}_{4}{ }^{+} / \\
\mathrm{C}_{4} \mathrm{H}_{2} \mathrm{~N}_{3} \mathrm{O}^{+}\end{array}$ & 108 & $12.22 \pm 0.2$ \\
\hline $\mathrm{C}_{3} \mathrm{H}_{3} \mathrm{~N}_{3}^{+}$ & 81 & $14.14 \pm 0.5$ & $\begin{array}{l}\mathrm{C}_{3} \mathrm{H}_{3} \mathrm{~N}_{3}{ }^{+} / \\
\mathrm{C}_{3} \mathrm{HN}_{2} \mathrm{O}^{+}\end{array}$ & 81 & $13.40 \pm 0.2$ \\
\hline $\mathrm{C}_{2} \mathrm{H}_{2} \mathrm{~N}_{2}^{+}$ & 54 & $14.55 \pm 0.3$ & $\begin{array}{l}\mathrm{C}_{2} \mathrm{H}_{2} \mathrm{~N}_{2}{ }^{+} / \\
\mathrm{C}_{2} \mathrm{NO}^{+}\end{array}$ & 54 & $14.10 \pm 0.3$ \\
\hline $\mathrm{C}_{2} \mathrm{HN}_{2}{ }^{+}$ & 53 & $16.72 \pm 0.5$ & $\mathrm{C}_{2} \mathrm{HN}_{2}^{+}$ & 53 & $15.58 \pm 0.5$ \\
\hline $\mathrm{HCNH}^{+}$ & 28 & $13.05 \pm 0.5$ & $\begin{array}{l}\mathrm{HCNH}^{+} / \\
\mathrm{CO}^{+}\end{array}$ & 28 & $13.79 \pm 0.4$ \\
\hline
\end{tabular}


Table 2. List of possible fragmentation reactions from adenine upon electron ionization and calculated (B3LYP/6-311+G(2d,p)) enthalpies (ZPE) for each reaction. The enthalpies are computed using the lowest energy conformer of the cation.

\begin{tabular}{|l|l|r|r|}
\hline & $\begin{array}{l}\text { Cation + neutral } \\
\text { (from adenine) }\end{array}$ & $\begin{array}{r}\text { Cation mass } \\
(\mathrm{m} / z)\end{array}$ & $\begin{array}{r}\text { B3LYP/6-311+G(2d,p) Enthalpy } \\
\text { (kcal/mol) }\end{array}$ \\
\hline$(3)$ & $\mathrm{C}_{4} \mathrm{H}_{4} \mathrm{~N}_{4}^{+}+\mathrm{HCN}$ & 108 & 95.9 \\
\hline$(4 \mathrm{a})$ & $\mathrm{C}_{3} \mathrm{H}_{3} \mathrm{~N}_{3}^{+}+2 \mathrm{HCN}$ & 81 & 102.9 \\
\hline$(4 \mathrm{~b})$ & $\mathrm{C}_{3} \mathrm{H}_{3} \mathrm{~N}_{3}^{+}+\mathrm{C}_{2} \mathrm{H}_{2} \mathrm{~N}_{2}$ & 81 & 140.1 \\
\hline$(5 \mathrm{a})$ & $\mathrm{C}_{2} \mathrm{H}_{2} \mathrm{~N}_{2}^{+}+3 \mathrm{HCN}$ & 54 & 134.5 \\
\hline$(5 \mathrm{~b})$ & $\mathrm{C}_{2} \mathrm{H}_{2} \mathrm{~N}_{2}^{+}+\mathrm{C}_{3} \mathrm{H}_{3} \mathrm{~N}_{3}$ & 54 & 138.5 \\
\hline$(6 \mathrm{a})$ & $\mathrm{C}_{2} \mathrm{HN}_{2}{ }^{+}+3 \mathrm{HCN}+\mathrm{H}$ & 53 & 191.8 \\
\hline$(6 \mathrm{~b})$ & $\mathrm{C}_{2} \mathrm{HN}_{2}{ }^{+}+\mathrm{C}_{3} \mathrm{H}_{4} \mathrm{~N}_{3}$ & 53 & 112.8 \\
\hline$(7 \mathrm{a})$ & $\mathrm{HCNH}^{+}+3 \mathrm{HCN}+\mathrm{CN}$ & 28 & 182.6 \\
\hline$(7 \mathrm{~b})$ & $\mathrm{HCNH}^{+}+\mathrm{C}_{4} \mathrm{H}_{3} \mathrm{~N}_{4}$ & 28 & 148.5 \\
\hline
\end{tabular}


Table 3. List of possible fragmentation reactions from hypoxanthine upon electron ionization and calculated (B3LYP/6-311+G(2d,p)) enthalpies (ZPE) for each reaction. The enthalpies are computed using the lowest energy conformer of the cation.

\begin{tabular}{|l|l|c|c|}
\hline & $\begin{array}{l}\text { Cation + neutral } \\
\text { (from hypoxanthine) }\end{array}$ & Cation mass $(m / z)$ & $\begin{array}{c}\text { B3LYP/6-311+G(2d,p) } \\
\text { Enthalpy (kcal/mol) }\end{array}$ \\
\hline$(8 \mathrm{a})$ & $\mathrm{C}_{4} \mathrm{H}_{2} \mathrm{~N}_{3} \mathrm{O}^{+}+\mathrm{HCNH}$ & 108 & 122.9 \\
\hline$(8 b)$ & $\mathrm{C}_{4} \mathrm{H}_{2} \mathrm{~N}_{3} \mathrm{O}^{+}+\mathrm{HCN}+\mathrm{H}$ & 108 & 143.8 \\
\hline$(8 \mathrm{c})$ & $\mathrm{C}_{4} \mathrm{H}_{4} \mathrm{~N}_{4}{ }^{+}+\mathrm{CO}$ & 81 & 22.6 \\
\hline$(9 \mathrm{a})$ & $\mathrm{C}_{3} \mathrm{H}_{3} \mathrm{~N}_{3}{ }^{+}+\mathrm{HCN}+\mathrm{CO}$ & 81 & 153.9 \\
\hline$(9 \mathrm{~b})$ & $\mathrm{C}_{3} \mathrm{HN}_{2} \mathrm{O}^{+}+2 \mathrm{HCN}+\mathrm{H}$ & 81 & 125.7 \\
\hline$(9 \mathrm{c})$ & $\mathrm{C}_{3} \mathrm{HN}_{2} \mathrm{O}^{+}+\mathrm{C}_{2} \mathrm{H}_{3} \mathrm{~N}_{2}$ & 54 & 115.6 \\
\hline$(10 \mathrm{a})$ & $\mathrm{C}_{2} \mathrm{H}_{2} \mathrm{~N}_{2}{ }^{+}+2 \mathrm{HCN}+\mathrm{CO}$ & 54 & 16.3 \\
\hline$(10 \mathrm{~b})$ & $\mathrm{C}_{2} \mathrm{H}_{2} \mathrm{~N}_{2}{ }^{+}+\mathrm{CO}^{+} \mathrm{C}_{2} \mathrm{H}_{2} \mathrm{~N}_{2}$ & 54 & 119.0 \\
\hline$(10 \mathrm{c})$ & $\mathrm{C}_{2} \mathrm{NO}^{+}+3 \mathrm{HCN}+\mathrm{H}$ & 54 & 172.8 \\
\hline$(10 \mathrm{~d})$ & $\mathrm{C}_{2} \mathrm{NO}^{+}+\mathrm{C}_{3} \mathrm{H}_{4} \mathrm{~N}_{3}$ & 53 & 97.5 \\
\hline$(11 \mathrm{a})$ & $\mathrm{C}_{2} \mathrm{HN}_{2}{ }^{+}+2 \mathrm{HCN}+\mathrm{CO}+\mathrm{H}$ & 53 & 163.6 \\
\hline$(11 \mathrm{~b})$ & $\mathrm{C}_{2} \mathrm{HN}_{2}{ }^{+}+\mathrm{C}_{3} \mathrm{H}_{3} \mathrm{~N}_{2} \mathrm{O}$ & 28 & 156.7 \\
\hline$(12 \mathrm{a})$ & $\mathrm{HCNH}^{+}+2 \mathrm{HCN}+\mathrm{CO}+\mathrm{CN}$ & 28 & 212.1 \\
\hline$(12 \mathrm{~b})$ & $\mathrm{HCNH}^{+}+\mathrm{C}_{4} \mathrm{H}_{2} \mathrm{~N}_{3} \mathrm{O}$ & 28 & 168.7 \\
\hline$(12 \mathrm{c})$ & $\mathrm{CO}^{+}+4 \mathrm{HCN}$ & & \\
\hline$(12 \mathrm{~d})$ & $\mathrm{CO}^{+}+\mathrm{C}_{4} \mathrm{H}_{4} \mathrm{~N}_{4}$ & 28 & 12.6 \\
\hline
\end{tabular}




\section{FIGURES}
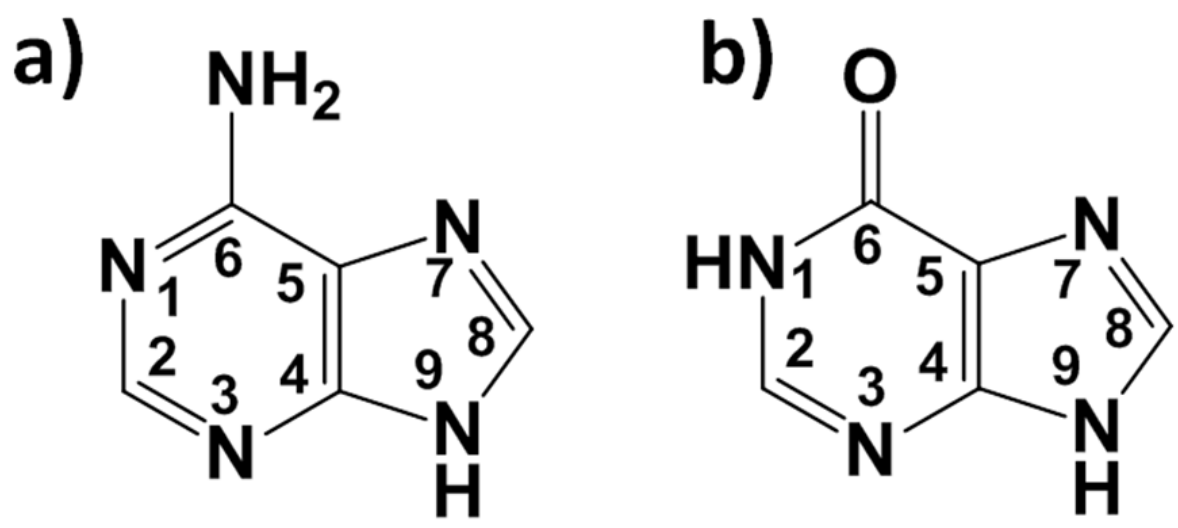

Fig. 1. Molecular structures of a) adenine and b) hypoxanthine investigated in this study. 

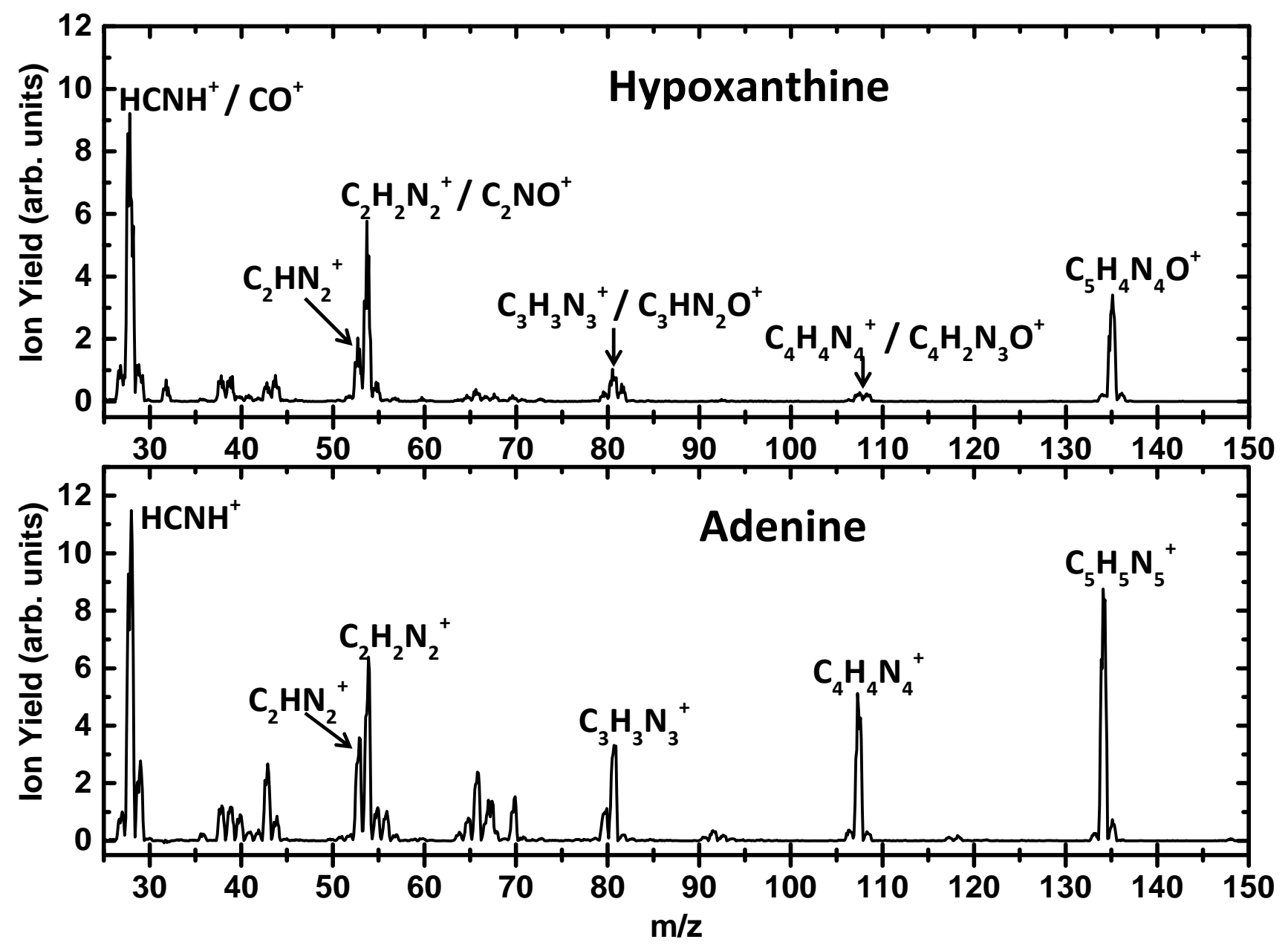

Fig. 2. Mass spectra obtained upon $70 \mathrm{eV}$ electron ionization of hypoxanthine (top) at an oven temperature of $453 \mathrm{~K}$ and of adenine (bottom) at an oven temperature of $421 \mathrm{~K}$. The parent and five most abundant cations for each molecule are labeled. 

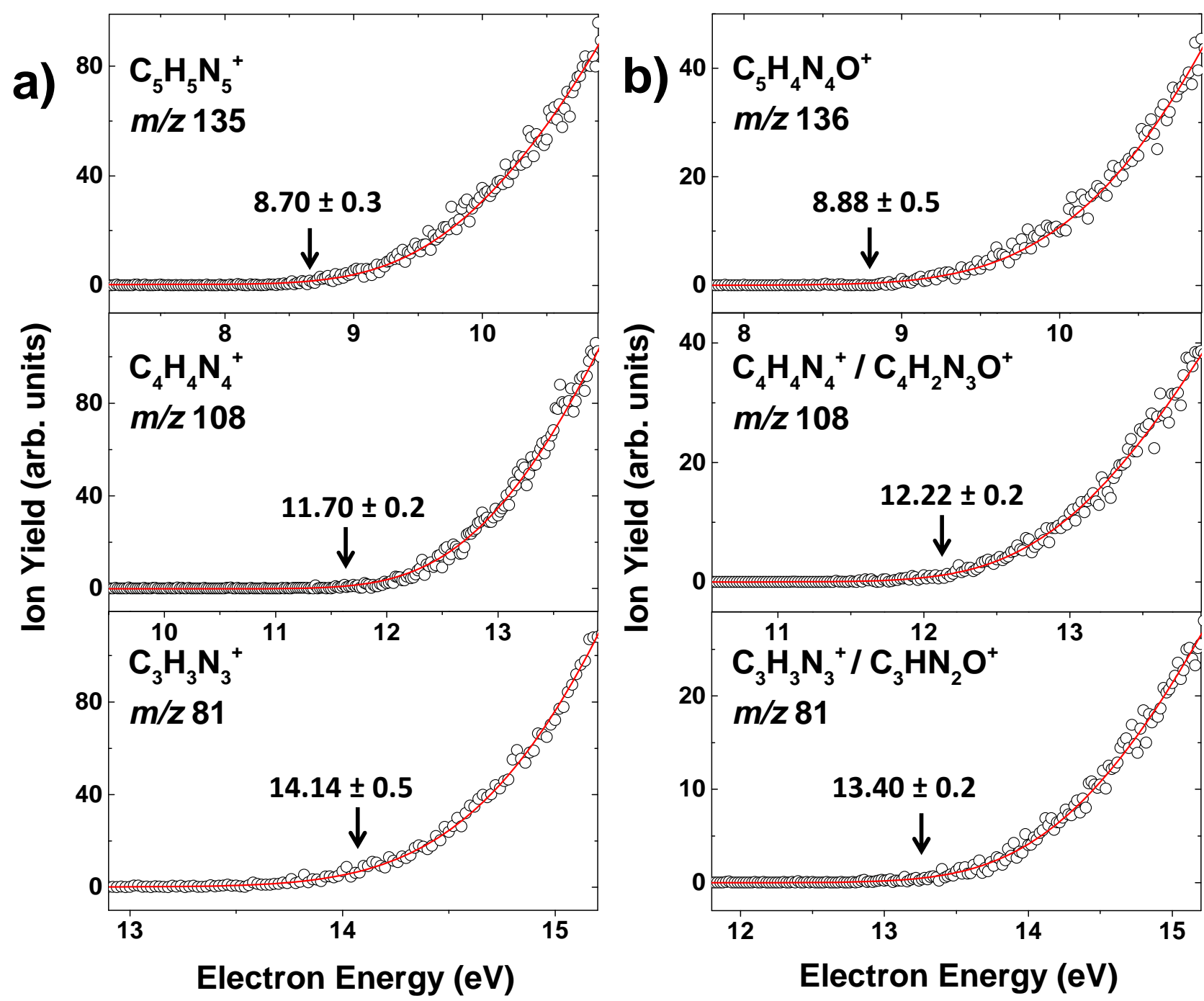

Fig. 3. Ion efficiency curves showing the threshold regions for a) $\mathrm{C}_{5} \mathrm{H}_{5} \mathrm{~N}_{5}{ }^{+}, \mathrm{C}_{4} \mathrm{H}_{4} \mathrm{~N}_{4}{ }^{+}$, and $\mathrm{C}_{3} \mathrm{H}_{3} \mathrm{~N}_{3}{ }^{+}$ cations from adenine (left column) at an oven temperature of $421 \mathrm{~K}$ and for b) $\mathrm{C}_{5} \mathrm{H}_{4} \mathrm{~N}_{4} \mathrm{O}^{+}, \mathrm{C}_{4} \mathrm{H}_{4} \mathrm{~N}_{4}^{+}$/ $\mathrm{C}_{4} \mathrm{H}_{2} \mathrm{~N}_{3} \mathrm{O}^{+}$, and $\mathrm{C}_{3} \mathrm{H}_{3} \mathrm{~N}_{3}{ }^{+} / \mathrm{C}_{3} \mathrm{HN}_{2} \mathrm{O}^{+}$cations from hypoxanthine (right column) at an oven temperature of $453 \mathrm{~K}$ measured upon electron ionization of the molecules. 

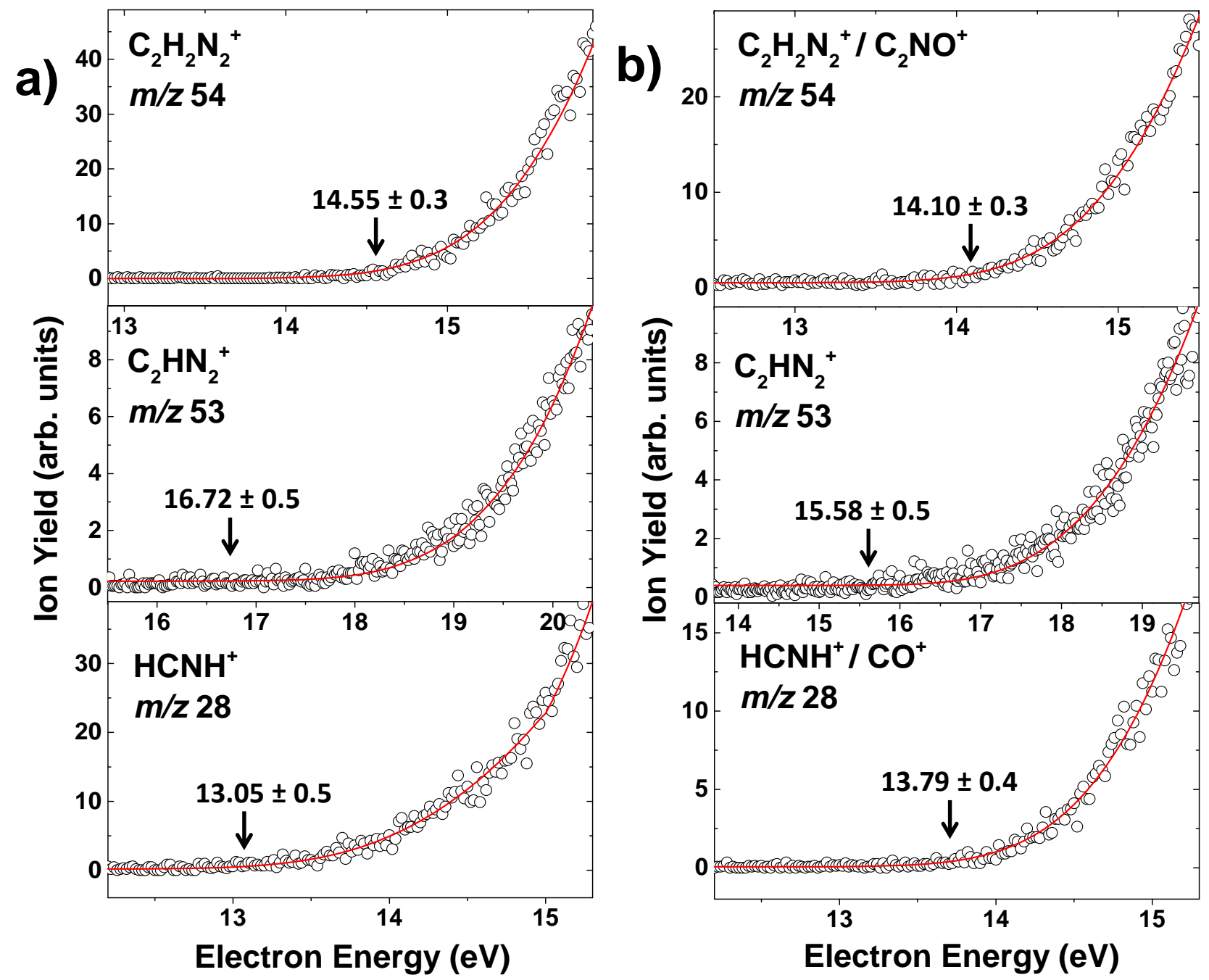

Fig. 4. Ion efficiency curves showing the threshold regions for a) $\mathrm{C}_{2} \mathrm{H}_{2} \mathrm{~N}_{2}{ }^{+}, \mathrm{C}_{2} \mathrm{HN}_{2}{ }^{+}$, and $\mathrm{HCNH}^{+}$ cations from adenine (left column) at an oven temperature of $421 \mathrm{~K}$ and for b) $\mathrm{C}_{2} \mathrm{H}_{2} \mathrm{~N}_{2}^{+} / \mathrm{C}_{2} \mathrm{NO}^{+}$, $\mathrm{C}_{2} \mathrm{HN}_{2}{ }^{+}$, and $\mathrm{HCNH}^{+} / \mathrm{CO}^{+}$cations from hypoxanthine (right column) at an oven temperature of $453 \mathrm{~K}$ measured upon electron ionization of the molecules. 


\section{Adenine, $m / z 135$}

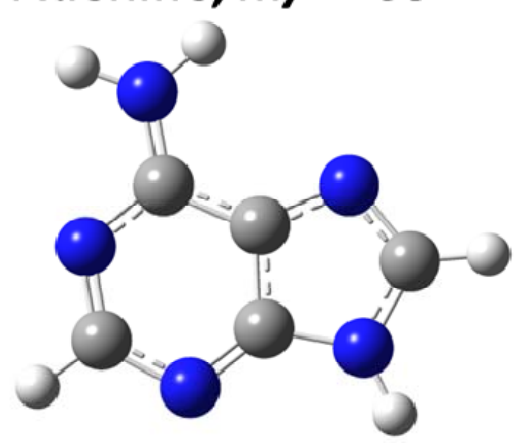

(1) $\mathrm{C}_{3} \mathrm{H}_{3} \mathrm{~N}_{3}{ }^{+}, m / 281$

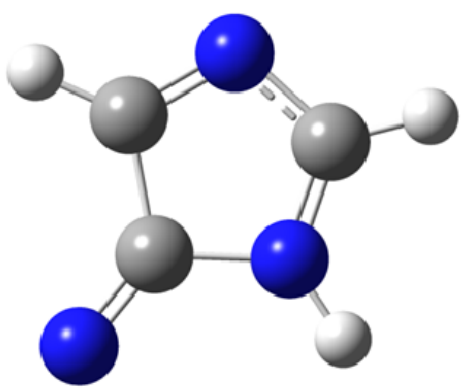

$\mathrm{C}_{2} \mathrm{H}_{2} \mathrm{~N}_{2}{ }^{+}, m / 254$

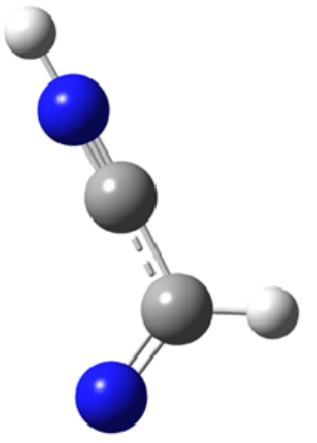

$\mathrm{C}_{4} \mathrm{H}_{4} \mathrm{~N}_{4}{ }^{+}, \mathrm{m} / \mathrm{z} 108$

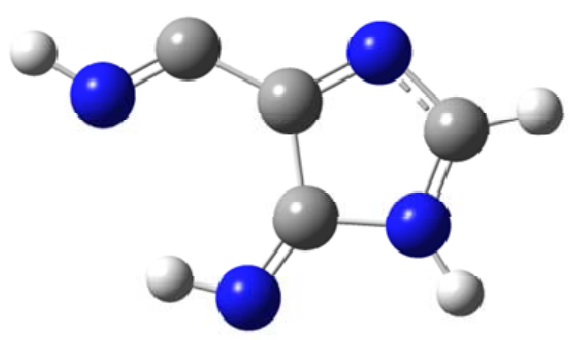

Carbon

- Nitrogen

Hydrogen

(2) $\mathrm{C}_{3} \mathrm{H}_{3} \mathrm{~N}_{3}{ }^{+}, \mathrm{m} / \mathrm{z} 81$ (+15 kcal/mol [0.65 eV])

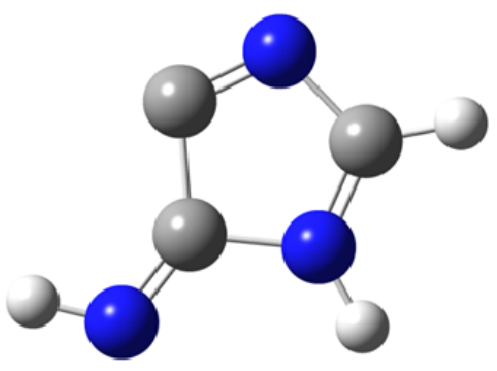

$\mathrm{C}_{2} \mathrm{HN}_{2}{ }^{+}, m / 253$

$\mathrm{HCNH}^{+}, m / 228$

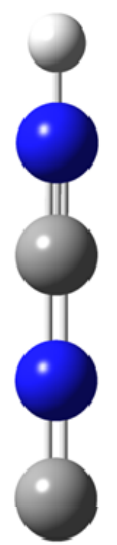

Fig. 5. Optimized structures $(B 3 L Y P / 6-311+G(2 d, p))$ for the parent molecule adenine and the major cations from adenine. Two low energy cations for $m / z 81$ were found, and the energy for structure (2) relative to the energy for structure (1) is shown. 


\section{$\mathrm{C}_{2} \mathrm{H}_{2} \mathrm{~N}_{2}$ neutral (4b)}

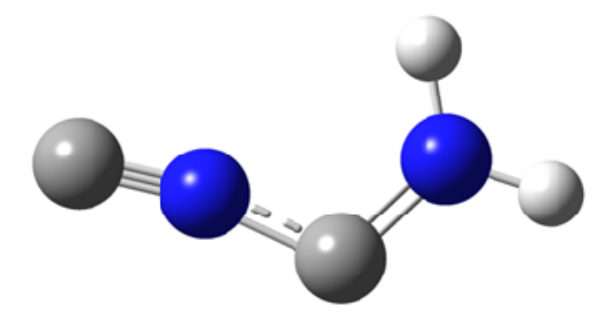

\section{$\mathrm{C}_{3} \mathrm{H}_{4} \mathrm{~N}_{3}$ neutral (6b)}

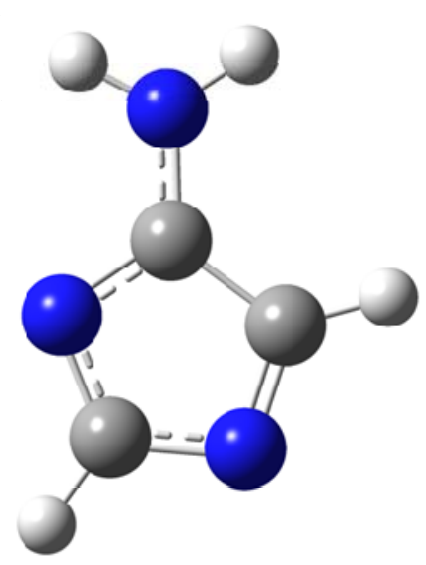

$\mathrm{C}_{3} \mathrm{H}_{3} \mathrm{~N}_{3}$ neutral (5b)

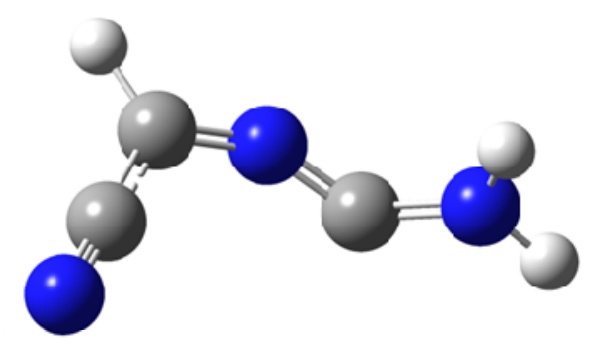

$\mathrm{C}_{4} \mathrm{H}_{3} \mathrm{~N}_{4}$ neutral (7b)

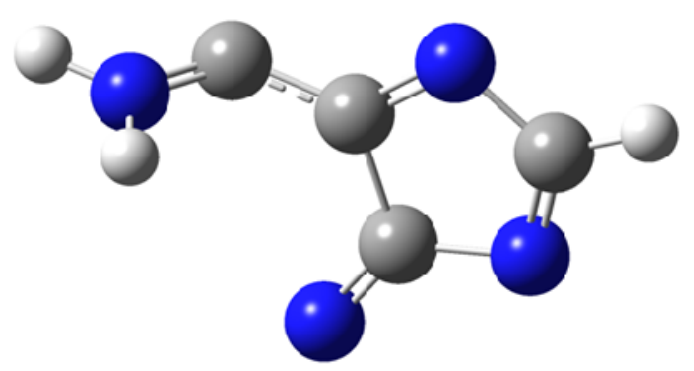

Fig. 6. Optimized structures $(B 3 L Y P / 6-311+G(2 d, p))$ for the most stable neutrals that accompany the cations in reactions $(4 b),(5 b),(6 b)$, and $(7 b)$ resulting from electron ionization of adenine. 

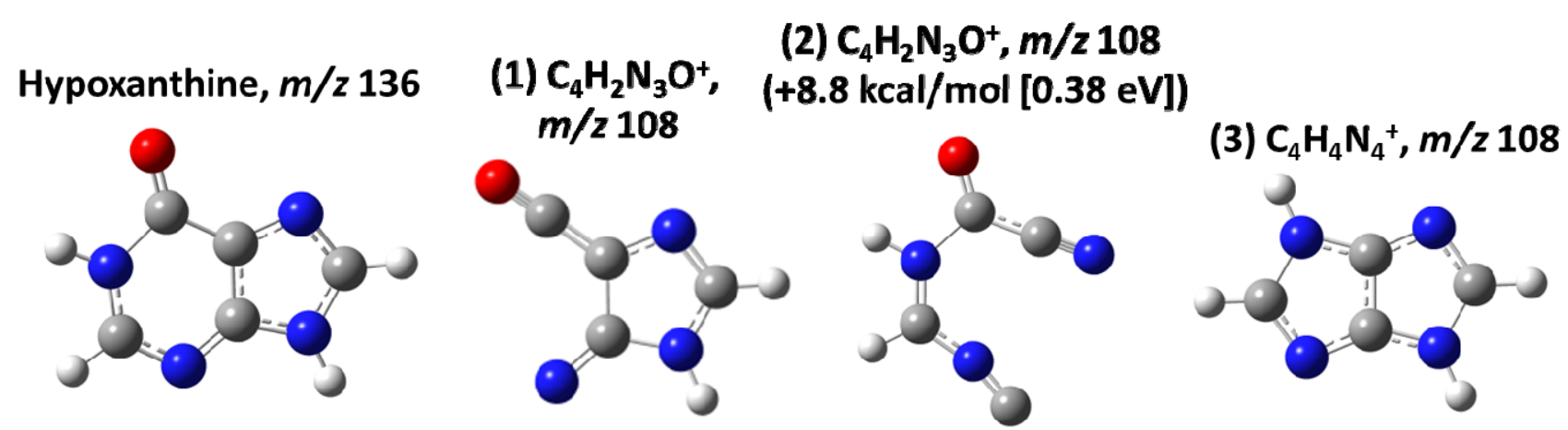

(1) $\mathrm{C}_{3} \mathrm{H}_{3} \mathrm{~N}_{3}{ }^{+}, m / z 81$

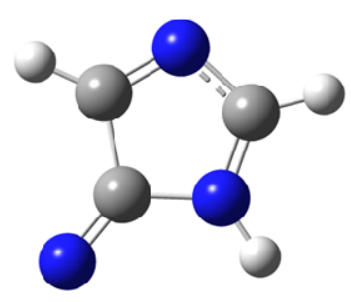

(2) $\mathrm{C}_{3} \mathrm{H}_{3} \mathrm{~N}_{3}{ }^{+}, \mathrm{m} / 281$ (+15 kcal/mol [0.65 eV])
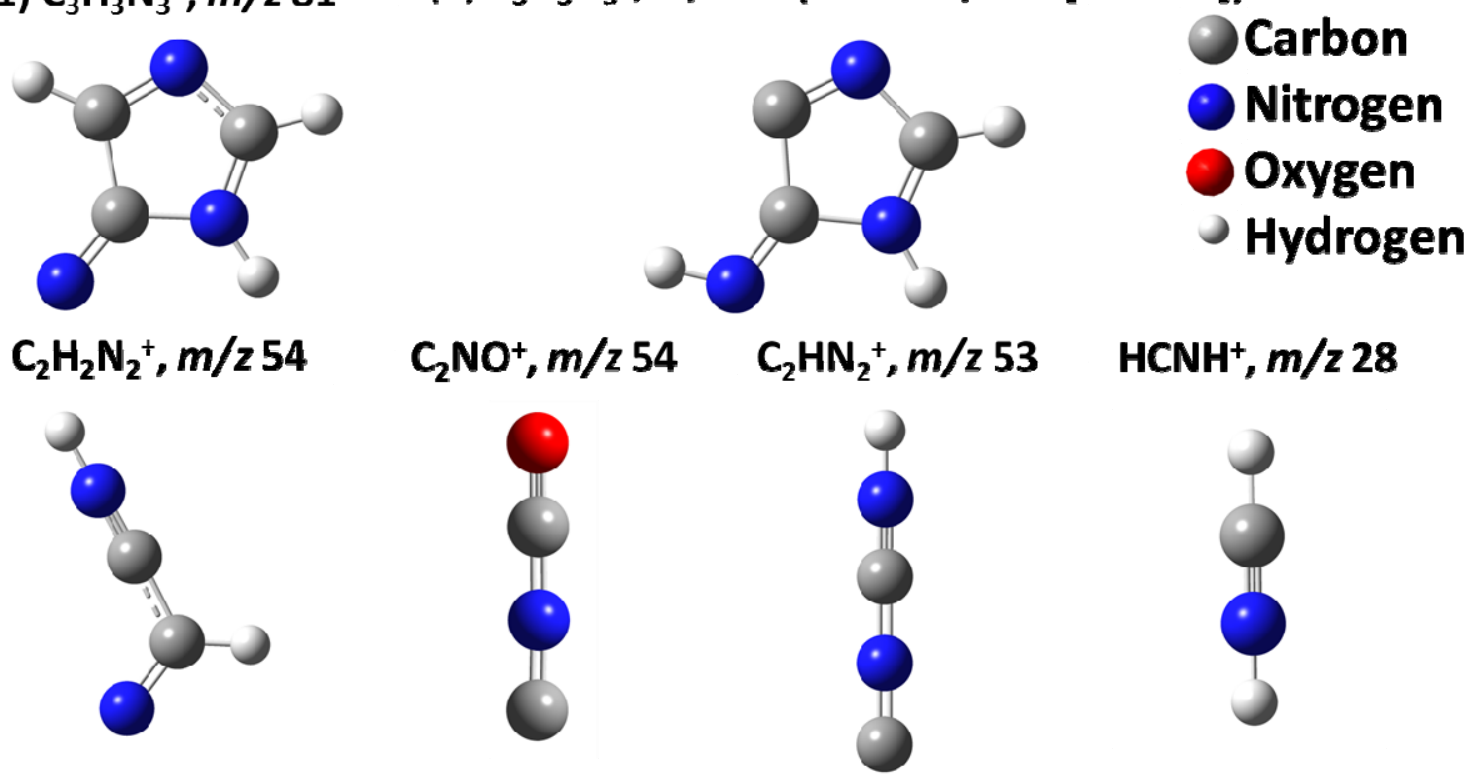

$\mathrm{HCNH}^{+}, \mathrm{m} / \mathbf{z} 28$

Fig. 7. Optimized structures $(B 3 L Y P / 6-311+G(2 d, p))$ for the parent molecule hypoxanthine and the major cations from hypoxanthine. Two low energy cations at $m / z 108$ representing $\mathrm{C}_{4} \mathrm{H}_{2} \mathrm{~N}_{3} \mathrm{O}^{+}$were found, while $\mathrm{C}_{4} \mathrm{H}_{4} \mathrm{~N}_{4}{ }^{+}$has a much higher energy. Two low energy cations for $m / z 81$ were also found. The energies for the second lowest energy structures (2) are shown relative to the lowest energy structures (1). 


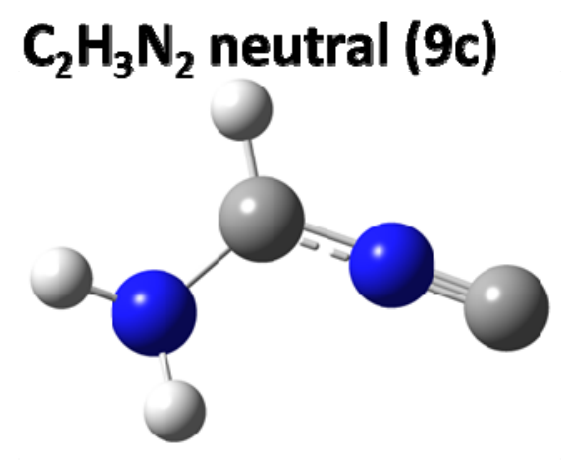

$\mathrm{C}_{3} \mathrm{H}_{4} \mathrm{~N}_{3}$ neutral (10d)

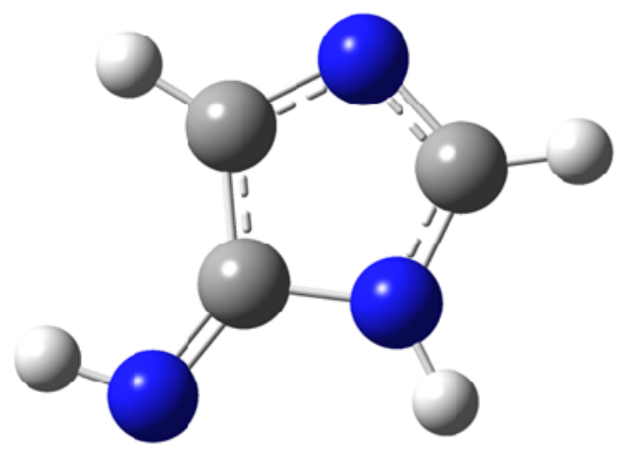

$\mathrm{C}_{4} \mathrm{H}_{2} \mathrm{~N}_{3} \mathrm{O}$ neutral (12b)

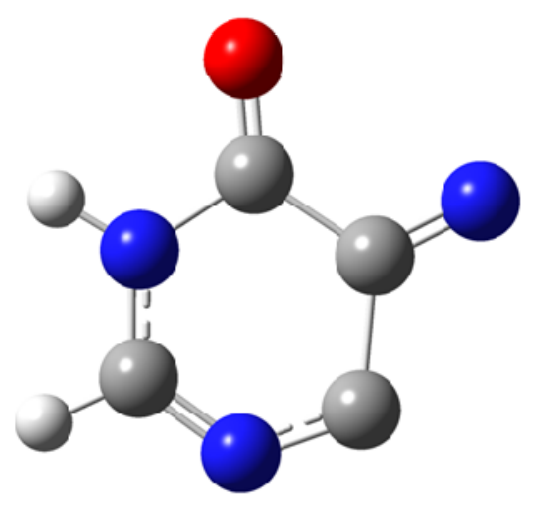

\section{$\mathrm{CO}+\mathrm{C}_{2} \mathrm{H}_{2} \mathrm{~N}_{2}$ neutrals (10b)}
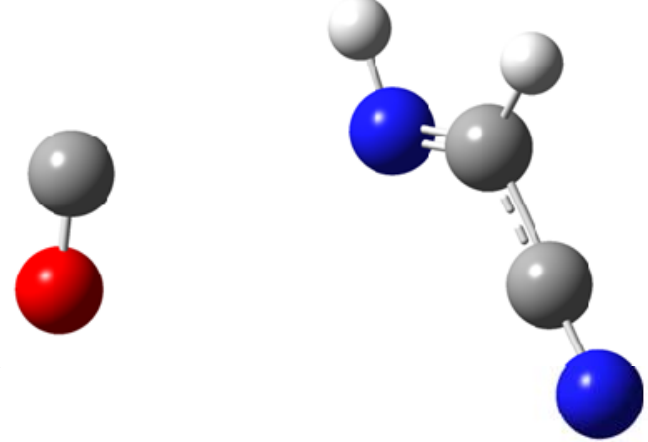

$\mathrm{C}_{3} \mathrm{H}_{3} \mathrm{~N}_{2} \mathrm{O}$ neutral (11b)

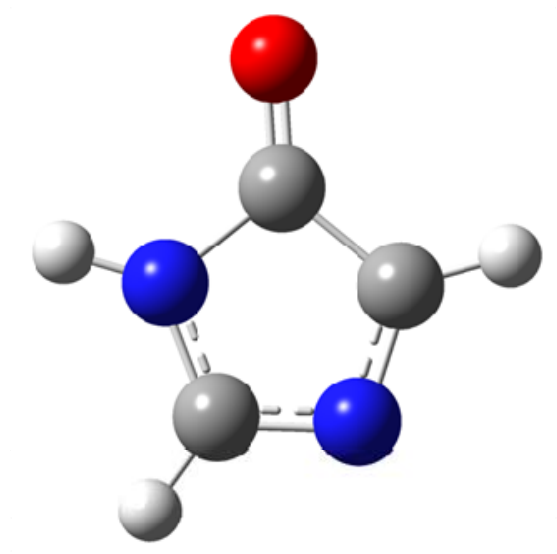

$\mathrm{C}_{4} \mathrm{H}_{4} \mathrm{~N}_{4}$ neutral (12d)

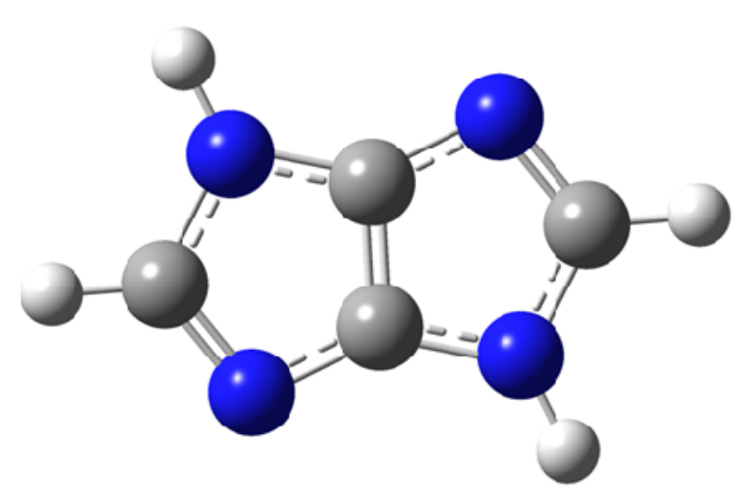

Fig. 8. Optimized structures (B3LYP/6-311+G(2d,p)) for the most stable neutrals that accompany the cations in reactions $(9 c),(10 b),(10 d),(11 b),(12 b)$, and $(12 d)$ resulting from electron ionization of hypoxanthine. 


\section{REFERENCES}

1. S. Kanvah, J. Joseph, G. B. Schuster, R. N. Barnett, C. L. Cleveland and U. Landman, Acc. Chem. Res., 2010, 43, 280-287.

2. H. Abdoul-Carime, J. Langer, M. A. Huels and E. Illenberger, EPJD, 2005, 35, 399-404.

3. H. Abdoul-Carime, S. Gohlke and E. Illenberger, Phys. Rev. Lett., 2004, 92, 168103.

4. L. Sanche, EPJD, 2005, 35, 367-390.

5. S. Ptasińska, S. Denifl, S. Gohlke, P. Scheier, E. Illenberger and T. D. Märk, Angew. Chem., 2006, 45, 1893-1896.

6. B. Boudaiffa, P. Cloutier, D. Hunting, M. A. Huels and L. Sanche, Sci, 2000, 287, 1658-1660.

7. X. Pan and L. Sanche, Phys. Rev. Lett., 2005, 94, 198104.

8. Shafranyosh, II, M. I. Sukhoviya, M. I. Shafranyosh and L. L. Shimon, Tech. Phys., 2008, 53, 1536-1540.

9. W. M. Huo, C. E. Dateo and G. D. Fletcher, Radiat. Measur., 2006, 41, 1202-1208.

10. N. L. Evans, C. J. Bennett, S. Ullrich and R. I. Kaiser, ApJ, 2011, 730, 69.

11. H. L. Barks, R. Buckley, G. A. Grieves, E. Di Mauro, N. V. Hud and T. M. Orlando, ChemBioChem, 2010, 11, 1240-1243.

12. J. S. Hudson, J. F. Eberle, R. H. Vachhani, L. C. Rogers, J. H. Wade, R. Krishnamurthy and G. Springsteen, Angew. Chem., 2012, 51, 5134-5137.

13. R. Saladino, C. Crestini, G. Costanzo, R. Negri and E. Di Mauro, Biorg. Med. Chem., 2001, 9, 1249-1253.

14. O. Botta and J. L. Bada, SGeo, 2002, 23, 411-467.

15. D. P. Zaleski, N. A. Seifert, A. L. Steber, M. T. Muckle, R. A. Loomis, J. F. Corby, O. Martinez, K. N. Crabtree, P. R. Jewell, J. M. Hollis, F. J. Lovas, D. Vasquez, J. Nyiramahirwe, N. Sciortino, K. Johnson, M. C. McCarthy, A. J. Remijan and B. H. Pate, Astrophys. J. Lett., 2013, 765, L10.

16. M. P. Callahan, K. E. Smith, H. J. Cleaves, J. Ruzicka, J. C. Stern, D. P. Glavin, C. H. House and J. P. Dworkin, Proc. Natl. Acad. Sci. U.S.A., 2011, 108, 13995-13998.

17. A. Shimoyama, S. Hagishita and K. Harada, Geochem. J., 1990, 24, 343-348.

18. C. Lifschitz, E. D. Bergmann and B. Pullman, Tetrahedron Lett., 1967, 4583-\&.

19. N. S. Hush and A. S. Cheung, Chem. Phys. Lett., 1975, 34, 11-13.

20. H. W. Jochims, M. Schwell, H. Baumgärtel and S. Leach, Chem. Phys., 2005, 314, 263-282.

21. S. Pilling, A. F. Lago, L. H. Coutinho, R. B. de Castilho, G. G. B. de Souza and A. N. de Brito, Rapid Commun. Mass Spectrom., 2007, 21, 3646-3652.

22. D. Touboul, F. Gaie-Levrel, G. A. Garcia, L. Nahon, L. Poisson, M. Schwell and M. Hochlaf, J. Chem. Phys., 2013, 138, 094203.

23. K. B. Bravaya, O. Kostko, S. Dolgikh, A. Landau, M. Ahmed and A. I. Krylov, J. Phys. Chem. $A, 2010,114,12305-12317$.

24. S. K. Sethi, S. P. Gupta, E. E. Jenkins, C. W. Whitehead, L. B. Townsend and J. A. McCloskey, J. Am. Chem. Soc., 1982, 104, 3349-3353.

25. B. F. Minaev, M. I. Shafranyosh, Y. Y. Svida, M. I. Sukhoviya, Shafranyosh, II, G. V. Baryshnikov and V. A. Minaeva, J. Chem. Phys., 2014, 140, 175101.

26. C. E. Crespo-Hernandez, R. Arce, Y. Ishikawa, L. Gorb, J. Leszczynski and D. M. Close, J. Phys. Chem. A, 2004, 108, 6373-6377.

27. O. Dolgounitcheva, V. G. Zakrzewski and J. V. Ortiz, J. Phys. Chem. A, 2009, 113, 1463014635.

28. S. Pacheco-Ortin, R. G. Lozano and E. A. Valdes, Int. J. Quantum Chem, 2012, 112, 28402847. 
29. S. D. Wetmore, R. J. Boyd and L. A. Eriksson, Chem. Phys. Lett., 2000, 322, 129-135.

30. M. Vinodkumar, C. Limbachiya, M. Barot, A. Barot and M. Swadia, Int. J. Mass Spectrom., 2014, 360, 1-7.

31. V. Feyer, O. Plekan, R. Richter, M. Coreno and K. C. Prince, Chem. Phys., 2009, 358, 33-38.

32. M. E. Costas and R. Acevedo-Chavez, J. Solution Chem., 2012, 41, 864-878.

33. F. Zappa, S. Denifl, I. Mahr, J. Lecointre, F. Rondino, O. Echt, T. D. Märk and P. Scheier, EPJD, 2007, 43, 117-120.

34. S. Denifl, B. Sonnweber, G. Hanel, P. Scheier and T. D. Märk, Int. J. Mass Spectrom., 2004, 238, 47-53.

35. A. N. Zavilopulo, O. B. Shpenik and A. S. Agafonova, J. Phys. B.-At., Mol. Opt. Phys., 2009, 42, 025101.

36. P. J. M. van der Burgt, EPJD, 2014, 68, 135.

37. C. Dal Cappello, Z. Rezkallah, S. Houamer, I. Charpentier, A. C. Roy, P. A. Hervieux and M. F. Ruiz-Lopez, EPJD, 2013, 67, 117.

38. L. S. Arani, P. Mignon, H. Abdoul-Carime, B. Farizon, M. Farizon and H. Chermette, Chem. Phys. Lett., 2013, 583, 165-169.

39. D. Close, G. Forde, L. Gorb and J. Leszczynski, Structural Chemistry, 2003, 14, 451-454.

40. S. Ptasińska, P. Candori, S. Denifl, S. Yoon, V. Grill, P. Scheier and T. D. Märk, Chem. Phys. Lett., 2005, 409, 270-276.

41. S. Ptasińska, S. Denifl, P. Scheier and T. D. Märk, Int. J. Mass Spectrom., 2005, 243, 171-176.

42. S. Denifl, B. Sonnweber, J. Mack, L. T. Scott, P. Scheier, K. Becker and T. D. Märk, Int. J. Mass Spectrom., 2006, 249-250, 353-358.

43. B. Puschnigg, S. E. Huber, M. Probst, K. Tanzer, V. Vizcaino, F. F. da Silva, P. Scheier, P. Limao-Vieira and S. Denifl, PCCP, 2013, 15, 3834-3840.

44. Alfa Aesar, http://www.alfa.com/en/GP100W.pgm?DSSTK=A11481, Accessed July 28, 2014.

45. M. Levy and S. L. Miller, Proc. Natl. Acad. Sci. U.S.A., 1998, 95, 7933-7938.

46. N. M. Erdevdi, V. V. Zvenigorodskii, O. B. Shpenik and L. G. Romanova, Opt. Spectrosc., 2013, 114, 47-51.

47. C. Plutzer and K. Kleinermanns, PCCP, 2002, 4, 4877-4882.

48. NIST Chemistry WebBook, http://webbook.nist.gov, 2013.

49. G. H. Wannier, Phys. Rev., 1953, 90, 817-825.

50. E. P. Wigner, Phys. Rev., 1948, 73, 1002-1009.

51. Python, https://www.python.org/, Accessed July 5, 2014.

52. SciPy, http://www.scipy.org/, Accessed July 5, 2014.

53. NumPy, http://www.numpy.org/, Accessed July 5, 2014.

54. Matplotlib, http://matplotlib.org/, Accessed July 5, 2014.

55. M. J. Frisch, G. W. Trucks, H. B. Schlegel, G. E. Scuseria, M. A. Robb, J. R. Cheeseman, G. Scalmani, V. Barone, B. Mennucci, G. A. Petersson, H. Nakatsuji, M. Caricato, X. Li, H. P. Hratchian, A. F. Izmaylov, J. Bloino, G. Zheng, J. L. Sonnenberg, M. Hada, M. Ehara, K. Toyota, R. Fukuda, J. Hasegawa, M. Ishida, T. Nakajima, Y. Honda, O. Kitao, H. Nakai, T. Vreven, J. Montgomery, J. E. Peralta, F. Ogliaro, M. Bearpark, J. J. Heyd, E. Brothers, K. N. Kudin, V. N. Staroverov, R. Kobayashi, J. Normand, K. Raghavachari, A. Rendell, J. C. Burant, J. M. Millam, S. S. Iyengar, J. Tomasi, M. Cossi, N. Rega, J. M. Millam, M. Klene, J. E. Knox, J. B. Cross, V. Bakken, C. Adamo, J. Jaramillo, R. Gomperts, R. E. Stratmann, O. Yazyev, A. J. Austin, R. Cammi, C. Pomelli, J. W. Ochterski, R. L. Martin, K. Morokuma, V. G. Zakrzewski, G. A. Voth, P. Salvador, J. J. Dannenberg, S. Dapprich, A. D. Daniels, O. Farkas, J. B. Foresman, J. V. Ortiz, J. Cioslowski and D. J. Fox, Gaussian, Inc., Wallingford, CT, 2009.

56. N. R. Brinkmann and I. Carmichael, J. Phys. Chem. A, 2004, 108, 9390-9399. 
57. C. T. Lee, W. T. Yang and R. G. Parr, Phys. Rev. B., 1988, 37, 785-789.

58. A. D. Becke, J. Chem. Phys., 1993, 98, 5648-5652.

59. D. Feller, J. Comput. Chem., 1996, 17, 1571-1586.

60. K. L. Schuchardt, B. T. Didier, T. Elsethagen, L. S. Sun, V. Gurumoorthi, J. Chase, J. Li and T. L. Windus, J. Chem. Inf. Mod., 2007, 47, 1045-1052.

61. W. S. Ohlinger, P. E. Klunzinger, B. J. Deppmeier and W. J. Hehre, J. Phys. Chem. A, 2009, $113,2165-2175$.

62. J. M. Rice and G. O. Dudek, J. Am. Chem. Soc., 1967, 89, 2719-2725.

63. CRC Handbook of Chemistry and Physics, http://www.hbcpnetbase.com, Accessed July 7, 2014.

64. E. V. Anslyn and D. A. Dougherty, in Modern Physical Organic Chemistry, University Science, Sausalito, CA, 2006, pp. 100-109.

65. E. R. Johnson and A. D. Becke, J. Chem. Phys., 2008, 128, 124105.

66. V. V. Afrosimov, A. A. Basalaev, Y. G. Morozov, M. N. Panov, O. V. Smirnov and E. A. Tropp, Tech. Phys., 2012, 57, 594-602. 